\title{
The Sistiana Fault and the Sistiana Bending Zone (SW Slovenia)
}

\author{
Sesljanski prelom in sesljanska upogibna cona \\ Ladislav PLACER, Petra JAMŠEK RUPNIK \& `Bogomir CELARC \\ Geološki zavod Slovenije, Dimičeva ul. 14, SI-1000 Ljubljana, Slovenija; \\ e-mail: ladislav.placer@telemach.net; petra.jamsek-rupnik@geo-zs.si;
}

Prejeto / Received 27. 9. 2021; Sprejeto / Accepted 24.11. 2021; Objavljeno na spletu / Published online 28. 12. 2021

Key words: Sistiana Fault, Sistiana Bending Zone, adjusting fault, Adria Microplate, Gulf of Trieste

Ključne besede: Sesljanski prelom, sesljanska upogibna cona, izravnalni prelom, Jadranska mikroplošča, Tržaški zaliv

\begin{abstract}
The Sistiana Fault is an alleged disjunctive deformation of Microadria in the sea bottom of the Gulf of Trieste. Onshore, it is visible only in the Sistiana Bay, but towards the northeast it soon pinches-out, in structuralgeometric terms it diminishes soon after the crossing of the thrust boundary of the Dinarides, or the IstrianFriuli Underthrustig Zone, respectively. Further to the northeast, only the bending zone is developed in the External Dinarides, which stretches all the way from the Sistiana Bay to the Idrija-Žiri area. We named it the Sistiana Bending Zone. Its direction can be determined based on geological maps and is around $60^{\circ}$, so we conclude that the Sistiana Fault should extend approximately in this direction. In the bending zone, the Trieste-Komen Anticlinorium, the Vipava Synclinorium, the Trnovo Nappe opposite to the Hrušica Nappe and the Raša and Idrija Faults are laterally bent. The size of the bend is the largest in the Sistiana Bay, and in the east-northeast direction it decreases linearly. The general geological circumstances suggest that the Sistiana Fault has not been recently active.
\end{abstract}

\section{Izvleček}

Sesljanski prelom je domnevna disjunktivna deformacija Mikroadrije v podmorju Tržaškega zaliva. Na površju je viden le v Sesljanskem zalivu, vendar se proti severovzhodu kmalu izklini, v strukturno-geometrijskem smislu izzveni kmalu zatem, ko preseka narivno mejo Dinaridov, oziroma istrsko-furlansko podrivno cono. Naprej proti severovzhodu je v Zunanjih Dinaridih razvita le še upogibna cona, ki se vleče vse od Sesljanskega zaliva do idrijsko-žirovskega ozemlja. Imenujemo jo sesljanska upogibna cona. Njena smer je določljiva na podlagi podatkov geoloških kart in znaša okoli $60^{\circ}$, zato sklepamo, da naj bi Sesljanski prelom potekal približno v tej smeri. V upogibni coni so bočno upognjeni Tržaško-Komenski antiklinorij, Vipavski sinklinorij, Trnovski pokrov nasproti Hrušiškemu pokrovu ter Raški in Idrijski prelom. Velikost upogiba je največja v Sesljanskem zalivu, proti vzhodu-severovzhodu pa se linearno manjša. Iz splošne geološke slike izhaja domneva, da Sesljanski prelom recentno ni aktiven.

\section{Introduction}

The plicative and disjunctive structures in the northwestern part of the External Dinarides in the hinterland of the Gulf of Trieste and Istra Peninsula are curved in the northwest direction (Fig. 1). This deformation was the result of the movement of the Adria Microplate Structural Block (Microadria) between the left-lateral strikeslip Sistiana Fault and the right-lateral strike-slip Kvarner Fault toward the Dinarides (Placer et al., 2010). This structural block was called the Istra Block, while the vast deformed hinterland area of

\section{Uvod}

V severozahodnem delu Zunanjih Dinaridov so plikativne in disjunktivne strukture v zaledju Tržaškega zaliva in polotoka Istre izbočene proti severovzhodu (sl. 1). Po Placerju in sodelavcih (2010) je deformacijo povzročilo premikanje strukturnega bloka Jadranske mikroplošče (Mikroadrije) med Sesljanskim in Kvarnerskim prelomom proti Dinaridom. Prvi naj bi bil levozmični, drugi desnozmični. Blok so poimenovali istrski blok, obsežno deformirano območje Dinaridov v zaledju pa istrsko potisno območje. 


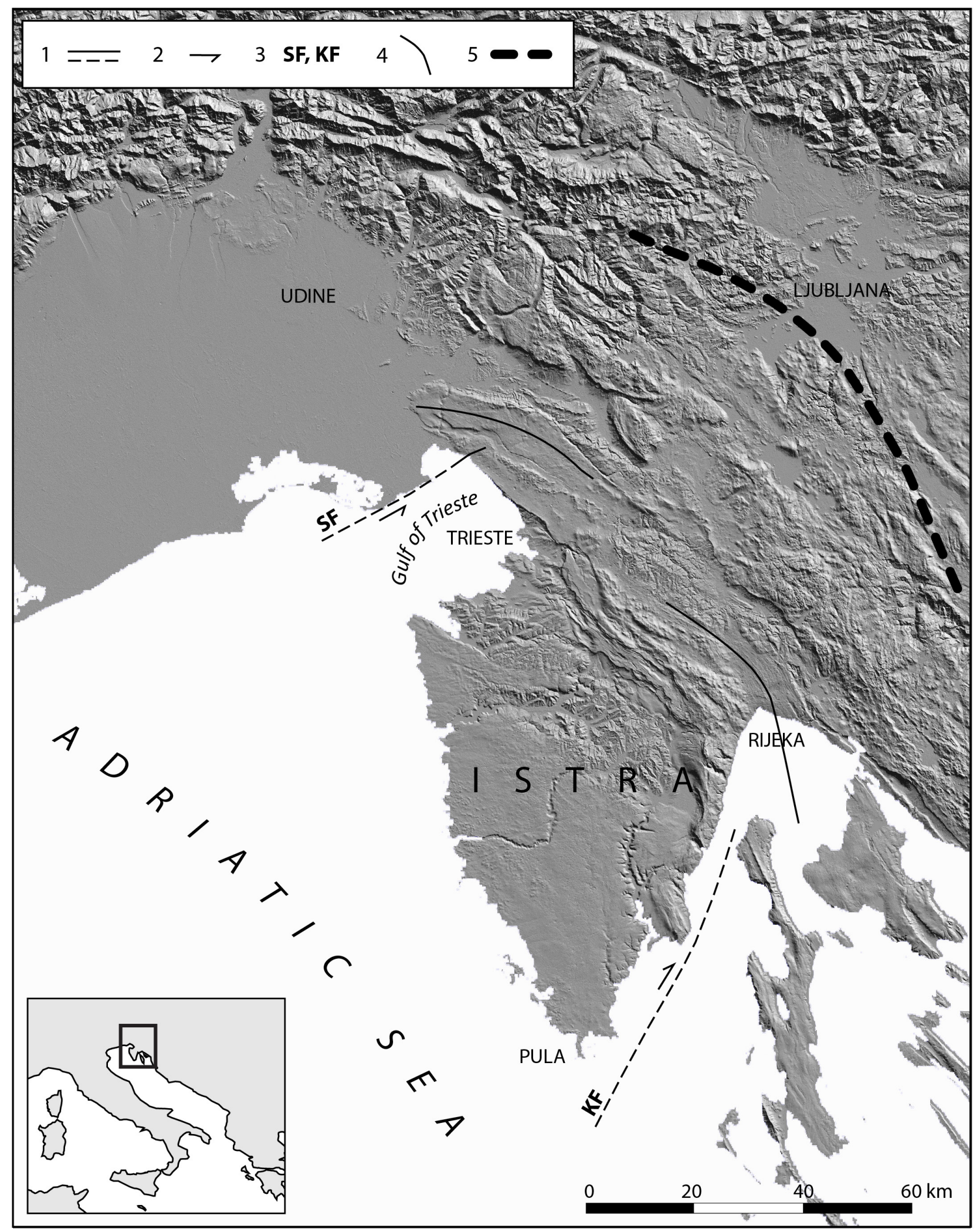

Fig. 1. Istra Pushed Area.

Sl. 1. Istrsko potisno območje.

1 Fault: proven, inferred / prelom: ugotovljen, domneven

2 Relative direction of the fault block displacement / relativna smer premika prelomnega krila $3 \mathrm{SF}$ - Sistiana Fault / Sesljanski prelom, KF - Kvarner Fault / Kvarnerski prelom 4 Laterally bent structures of Dinarides / bočno upognjene strukture Dinaridov

5 Approximate boundaries of the Istra Pushed Area effects / približna meja vidnih učinkov istrskega potisnega območja 
the Dinarides was named the Istra Pushed Area. While the exact direction of the block's movement has not yet been established, it could be assumed, in view of the recent orientation of Microadria, that the block traveled in a northeasterly to easterly direction. While this was a multiphase event, details of the exact timing of such have not yet been determined.

Northwest of the Sistiana Fault, along with the Istra Block, also the Friuli Block was displaced toward the Dinarides, but not to such an extent as the Istra Block, owing to the geometry of the displacements. Consequently, the Istra Block was the northeastern-most displaced part of Microadria.

The theory of underthrusting and pushing against the Dinarides (Placer et al., 2010) is based on analysis of existing geological maps and field investigations. The Čičarija and Trieste-Komen Anticlinorioum formed mainly as the result of Dinaric thrusting, while its lateral deformation developed later, definitely during the pushing of the Istra Block against the Dinarides. Underthrusting was the extreme expression and consequence of these movements, while the entire area experienced a multiphase contraction in the form of folding and displacements along secondary reverse faults.

Blašković \& Aljinović (1981) and Blašković (1991) already discussed this pushing toward the Dinarides in the Istra and Kvarner areas. Carulli \& Cucchi (1991) first described the Sistiana Fault in the Sistiana Bay northwest of Trieste. Later, different aspects of it were investigated by Carulli (2006, 2011), Busetti et al. (2010), Placer et al. (2010), Cucchi \& Piano (2013), Placer (2015) and others. It was discovered that it pinches out after a few kilometers from the shore inland, in the NE direction, while in the offshore direction it continues below the sea-bottom towards the southwest. In the northeast, in the direction of the fault's apparent continuation, there are laterally-bent Dinaric structures. Their axis of bending could be approximately determined, therefore Placer et al. (2010, Fig. 27) introduced the term Sistiana Zone and established its direction. Displacements along the Sistiana Fault were determined as a left-lateral strike-slip based on the position of the bent structures.

In eastern Istria, opposite the Sistiana Zone, we find bent structures in a mirrored configuration that are probably connected with the supposed Kvarner Fault in the SSW-NNE direction. The direction and position of the bent structures can be determined in the same way as they can for the Sistiana Zone, although the axis of bending is
Natančnejša smer premika bloka še ni določena, vsekakor pa se je, glede na današnjo orientacijo Mikroadrije, pomaknil proti severovzhodu do vzhodu. Dogajanje je bilo večfazno, pričetek še ni natančneje ugotovljen.

Poleg istrskega bloka naj bi bil proti Dinaridom pomaknjen tudi furlanski blok severozahodno od Sesljanskega preloma, vendar je zaradi geometrije premikov istrski blok najbolj proti severovzhodu potisnjeni del tega dela Mikroadrije.

Ideja o podrivanju in potiskanju proti Dinaridom (Placer et al., 2010) je utemeljena na analizi podatkov geoloških kart in terenskega opazovanja. Čičarijski in Tržaško-Komenski antiklinorij sta v glavnem nastala pri narivanju Dinaridov, njuna bočna deformacija pa je nastala pozneje, vsekakor pri potiskanju istrskega bloka proti Dinaridom. Pri tem se je v najbolj ekstremnih primerih uveljavilo podrivanje, na celotnem območju pa stiskanje prostora v obliki gubanja in premikov ob sekundarnih reverznih prelomih. Dogajanje je bilo večfazno.

O strukturah potiskanja proti Dinaridom na območju Istre in Kvarnerja sta pisala že Blašković in Aljinović (1981) in Blašković (1991). Sesljanski prelom sta v Sesljanskem zalivu, severozahodno od Trsta, odkrila Carulli in Cucchi (1991), pozneje so ga iz različnih vidikov obravnavali Carulli (2006, 2011), Busetti in sodelavci (2010), Placer in sodelavci (2010), Cucchi in Piano (2013), Placer (2015) idr. Pri teh raziskavah je bilo ugotovljeno, da se od obale proti severovzhodu že po nekaj kilometrih izklini, proti jugozahodu pa naj bi se domnevno nadaljeval v podmorju Tržaškega zaliva. Na severovzhodu, kjer ni več preloma, se v njegovi smeri nahajajo bočno upognjene dinarske strukture, katerih os upogiba je mogoče približno določiti, zato so Placer in sodelavci (2010, sl. 27) uporabili izraz sesljanska cona in ji določili smer. Glede na lego upognjenih struktur, so vsi raziskovalci opredelili Sesljanski prelom kot levi zmik.

Nasproti sesljanske cone ležijo v vzhodni Istri v zrcalni legi upognjene strukture, ki naj bi bile povezane z domnevnim Kvarnerskim prelomom v smeri SSW-NNE. Enako kot sesljanski coni je mogoče tudi tu upognjenim strukturam določiti smer in lego, vendar os upogiba tu ne leži neposredno v podaljšku domnevnega Kvarnerskega preloma. Govorimo o kvarnerski coni, ki pa je bistveno večja in kompleksnejša od sesljanske. Kvarnerski prelom ne izdanja nikjer, kot hipotetičnega sta ga zaradi neskladja med zgradbo Istre in otoka Cresa uvedla Šikić in Polšak (1973). Pojem Kvarnerskega preloma je potrebno razumeti 


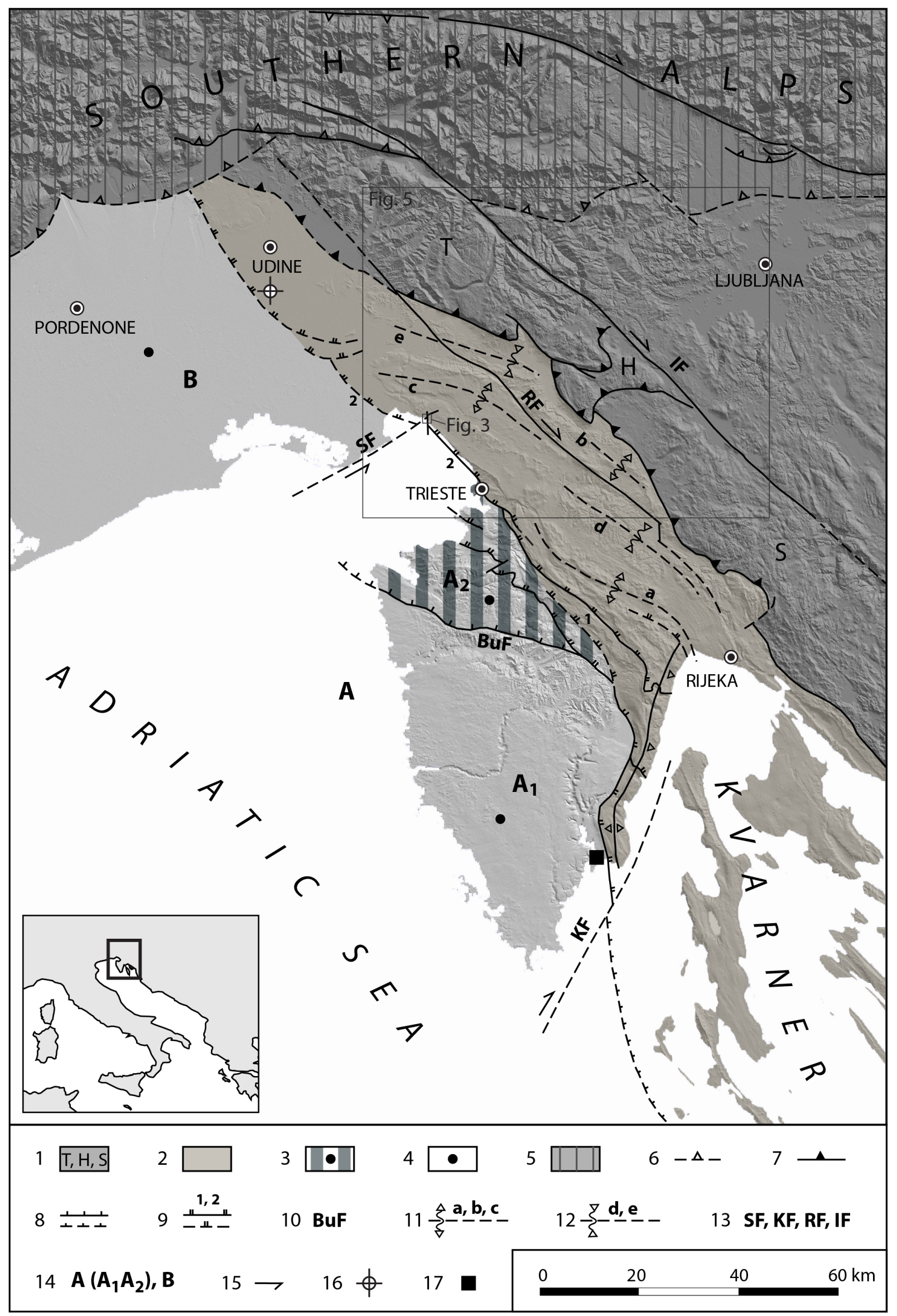

Fig. 2. Structural sketch of the Istra Pushed Area. Amended after Placer et al. (2010, Fig. 4). Basic data according to Basic geological map of Yugoslavia (OGK) and Carulli (2006).

Sl. 2. Strukturna skica istrskega potisnega območja. Dopolnjeno po Placer et al. (2010, sl. 4). Osnovni podatki Osnovna geološka karta Jugoslavije (OGK) in Carulli (2006). 
not positioned in the continuation of the supposed Kvarner Fault. This is the Kvarner Zone, and it is significantly larger and more complex compared to the Sistiana Zone. There are no known outcrops of the Kvarner Fault. Due to the disparity between the structures of Istra and the island of Cres, it was introduced by Šikić \& Polšak (1973). The term Kvarner Fault needs to be understood in the wider sense, as it could represent a fault or a wider and more complex tectonic zone of uncertain origin.

In the coastal area, structures in the northwestern block of the Sistiana Zone strike in the W-E direction (the northwest part of the Trieste-Komen Anticlinorium), while in the southeastern block of the Kvarner Zone (southeastern part of the Čičarija Anticlinorium, Cres Island), structures strike in the N-S direction. The Istra Pushed Area therefore took on a semicircular shape, which covers the frontal part of the Dinarides between the Southern Alps and the central Kvarner area, while in the interior its effects are visible up to the Ljubljana Basin (Placer, 2008; Placer et al., 2010, Fig. 27; Placer et al., 2921).

The flexural structures associated with the Kvarner Fault occupy a far larger area than those in the extension of the Sistiana Fault. They also have a significantly more complex structure, with overprinting deformations from different evolutionary stages, which makes their study more difficult. Therefore, the Sistiana Zone is more suita- širše, lahko da gre resnično za prelom, lahko pa za široko in kompleksno tektonsko cono nejasne geneze.

Strukture v severozahodnem krilu sesljanske cone imajo v priobalnem pasu smer W-E (severozahodni del Tržaško-Komenskega antiklinorija), v jugovzhodnem krilu kvarnerske cone pa imajo smer N-S (jugovzhodni del Čičarijskega antiklinorija, otok Cres). Istrsko potisno območje ima zaradi tega polkrožno obliko, ki zajema čelni del Dinaridov med Južnimi Alpami in osrednjim Kvarnerjem, v notranjost pa sega njen vidni učinek nekako do Ljubljanske kotline (Placer, 2008; Placer et al., 2010, sl. 27; Placer et al., 2021).

Upognjene strukture povezane s Kvarnerskim prelomom zavzemajo mnogo večji prostor kot tiste v podaljšku Sesljanskega preloma. Imajo tudi kompleksnejšo zgradbo, kar pomeni, da se v njih prekrivajo deformacije različnih stopenj razvoja, zaradi česar je njihovo proučevanje težavnejše. Zato je sesljanska cona primernejša za pilotsko raziskavo geneze prečno upognjenih struktur Zunanjih Dinaridov.

Zaradi terminološke korektnosti je izraz sesljanska cona dopolnjen z opisom tipa in smeri deformiranja, zato smo uporabili izraz sesljanska bočno upogibna cona, skrajšano sesljanska upogibna cona. Enako velja za kvarnersko cono, oziroma kvarnersko bočno upogibno cono, skrajšano kvarnersko upogibno cono.

Fig. 2. / Sl. 2.

1 Dinarides: External Dinaric Thrust Belt: T-Trnovo Nappe, H-Hrušica Nappe, S-Snežnik Nappe / Dinaridi: Zunanjedinarski narivni pas: T - Trnovski pokrov, H - Hrušiški pokrov, S - Snežniški pokrov

2 Dinarides: External Dinaric Imbricate Belt / Dinaridi: Zunanjedinarski narivni pas

3 Microadria: Parautochton sensu stricto / Mikroadrija: paravtohton sensu stricto

4 Microadria: Stabile core / Mikroadrija: stabilno jedro

5 Southern Alps / Južne Alpe

6 Southern Alps Thrust boundary / meja narivne cone Južnih Alp

7 External Dinaric Thrust Belt boundary / meja Zunanjedinarskega narivnega pasu

8 Boundary of the Dinarides / meja Dinaridov

9 Istra-Friuli Underthrust Zone: 1 - Črni Kal Thrust Fault, 2 - Palmanova Thrust Fault / istrsko-furlanska podrivna cona: 1 - Črnokalski narivni prelom, 2 - Palmanovski narivni prelom

$10 \mathrm{BuF}$ - Buje reverse Fault / Bujski reverzni prelom

11 Anticlinorium: a - axis of the Čičarija Anticlinorium, b - axis of the Ravnik Anticlinorium, c - axis of the Trieste-Komen Anticlinorium / antiklinorij: a - os Čičarijskega antiklinorija, b - os Ravenskega antiklinorija, c - os Tržaško-Komenskega antiklinorija

12 Synclinorium: d - axis of the Brkini Synclinorium, e - axis of the Vipava Synclinorium / sinklinorij, d - os Brkinskega sinklinorija, e - os Vipavskega sinklinorija

13 Important sub-vertical faults: SF - Sistiana Fault, KF - Kvarner Fault, RF - Raša Fault, IF - Idrija Fault / pomembnejši subvertikalni prelomi: SF - Sesljanski prelom, KF - Kvarnerski prelom, RF - Raški prelom, IF - Idrijski prelom

14 Microadria structural block: A - Istra Block $\left(\mathrm{A}_{1}\right.$ - South Istra Structural Wedge, $\mathrm{A}_{2}$ - North Istra Structural Wedge), B Friuli Block / strukturni blok Mikroadrije: $\mathrm{A}$ - istrski blok ( $\mathrm{A}_{1}$ - južnoistrski strukturni klin, $\mathrm{A}_{2}$ - severnoistrski strukturni klin), B - furlanski blok

15 Relative displacement direction / relativna smer premika

16 Cargnacco 1 borehole / vrtina Cargnacco 1

17 Koromačno Bay / zaliv Koromačno 
ble for the pilot investigations of the transversely bent structures of the External Dinarides.

In order to apply a correct and common terminology, the term Sistiana Zone is supplemented with a description of the type and direction of deformation, which is why we have used the term Sistiana Lateral Bending Zone, abbreviated as Sistiana Bending Zone. The same applies for the Kvarner Zone, or the Kvarner Lateral Bending Zone, abbreviated as Kvarner Bending Zone.

The tectonic push also resulted in the underthrusting of the Istra-Friuli Underthrust Zone, which is strongly emphasized on the northeastern boundary of the Istrian Block, but is significantly weaker in the Friuli Block.

The structural sketch of the Istra Pushed Area (Fig. 2) is simplified and amended after Placer et al. (2010, Fig. 4). The Southern Alps are separated, but internally remain undivided. The Dinarides are divided in the context of the thrust structure into the External Dinaric Thrust Belt and the External Dinaric Imbricate Belt. Microadria is divided into the imbricated edge of the autochthone or parautochtone sensu stricto and autochthone. The boundary between both units is the Buje Reverse Fault $(\mathrm{BuF})$. The Istra Block is denominated with A, and the Friuli Block with B. The Istra Block is further subdivided into two structural wedges, namely the South Istrian $\left(\mathrm{A}_{1}\right)$ and the North Istrian $\left(\mathrm{A}_{2}\right)$ Structural Wedge.

The Istra-Friuli Underthrust Zone is segmented: the central fault structures in the zone are the Crni Kal and Palmanova thrust faults. The first can be ascribed to the Učka Thrust, while second the can be traced also northwest from the Sistiana Fault based on deep borehole data and geophysical sounding (Nicolich et al., 2004, Tavola 1, Tavola 2; Carulli, 2006). The Istra-Friuli Underthrust Zone stretches to the Kvarner Fault in the southeastern direction. According to the field investigations, the Istra-Friuli Underthrust Zone is the most tectonically deformed at the tip of the South Istra Structural Wedge. Available data from the Cargnacco 1 borehole well south of Udine (Venturini, 2002) and from the last visible outcrop of the Dinarides thrust boundary in Koromačno on the eastern coast of Istra point (Fig. 2) to the proportionally lesser tectonic deformation.

It is clear from the general structural sketch of the Istra Pushed Area that the deformations of underthrusting and pushing due to the activity of the Microadria are most pronounced in the extension of the axis of the South Istrian Structural Wedge, where the Čičarija Anticlinorium and the Brkini Synclinorium are bent due to lateral push
Posledica potiskanja v istrsko-furlanski podrivni coni je bilo tudi podrivanje, ki je močno poudarjeno na severovzhodni meji istrskega bloka, bistveno šibkeje pa v furlanskem bloku.

Strukturna skica istrskega potisnega območja na sliki 2 je povzeta po Placerju in sodelavcih $(2010$, sl. 4) ter poenostavljena in dopolnjena. Južne Alpe so ločene toda nerazčlenjene, Dinaridi so razčlenjeni $\mathrm{v}$ smislu narivne zgradbe na Zunanjedinarski narivni pas in Zunanjedinarski naluskani pas, Mikroadrija je razdeljena na naluskani rob avtohtona ali paravtohton sensu stricto in avtohton. Meja med obema enotama je Bujski reverzni prelom (BuF). Istrski blok je označen $z$ $A$, furlanski blok z B. Istrski blok je nadalje razdeljen na dva strukturna klina, južnoistrski $\left(A_{1}\right)$ in severnoistrski strukturni klin $\left(\mathrm{A}_{2}\right)$.

Istrsko-furlanska podrivna cona je segmentirana; osrednji prelomni strukturi v njej sta Črnokalski in Palmanovski narivni prelom. Prvega je mogoče povezati z narivom Učke, drugega pa je mogoče na podlagi podatkov globokih vrtin in geofizikalnega sondiranja (Nicolich et al., 2004, tavola 1, tavola 2; Carulli, 2006) slediti tudi severozahodno od Sesljanskega preloma. Proti jugovzhodu sega istrsko-furlanska podrivna cona formalno do Kvarnerskega preloma. Po podatkih terenskega profiliranja je istrsko-furlanska podrivna cona najbolj tektonizirana v konici južnoistrskega strukturnega klina. Dostopni podatki vrtine Cargnacco 1 južno od Vidma/Udin (Venturini, 2002) in na skrajnem vidnem izdanku narivne meje Dinaridov v Koromačnem na vzhodni obali Istre (sl. 2) kažejo na sorazmerno manjšo stopnjo porušenosti.

Iz splošne strukturne skice istrskega potisnega območja izhaja, da so deformacije podrivanja in potiskanja zaradi aktivnosti Mikroadrije najbolj izražene v podaljšku osi južnoistrskega strukturnega klina, kjer sta zaradi bočnega potiska usločena Čičarijski antiklinorij in Brkinski sinklinorij (a in d na sl. 2). Potisk je kombiniran s podrivanjem; pod istrsko-furlansko podrivno cono je proti VSV potisnjen jugovzhodni del Bujskega preloma (BuF) in skupaj z njim ustrezni del paravtohtona sensu stricto, pod Snežniški pokrov pa del severovzhodnega krila Brkinskega sinklinorija in jugovzhodni del Ravniškega antiklinorija.

Sesljanski prelom je del vertikalne segmentacije Mikroadrije, sesljanska bočno upogibna cona pa je prizadela Zunanjedinarski naluskani in Zunanjedinarski narivni pas. Zaradi tako jasnih razmerij med Mikroadrijo in Dinaridi nudi to območje možnosti za posredno ugotavljanje 
(a and d on Fig. 2). The pushing is combined with underthrusting; beneath the Istrian-Friuli Underthrusting Zone, the southeastern part of the Buje Fault (BuF) and its corresponding part of the autochthonous sensu stricto are pushed, while part of the northeastern limb of the Brkini Synclinorium and the southeastern part of the Ravnik Anticlinorium is pushed under the Snežnik Nappe.

The Sistiana Fault is part of the vertical segmentation of the Microadria, and the Sistiana Lateral Bending Zone affected the External Dinaric Imbricate Belt and Thrust Belt. Due to such clear relationships between the Microadria and the Dinarides, this area offers the opportunity to indirectly determine in depth the geometric relationship between these two units and provide the necessary data for structural modeling.

\section{Sistiana Fault}

The Sistiana Fault is visible on the surface only along the coast of the Sistiana Bay. A structural sketch of the vicinity of the bay is represented in Fig. 3A and is based on data from the Carta Geologica del Carso Classico Italiano (Cucchi \& Piano, 2013) and our own investigations. All main components of the composition were confirmed: the Sistiana Fault (I), the N-S directed fault (II), and the Trieste reverse fault (III), which is part of the thrust system of the wider area. There are flysch and marlstone outcroppings between faults no. I and II, while the neighboring units are composed of Cretaceous, Paleocene, and Eocene limestones. Flysch beds appear in the inverse position.

The Sistiana Fault outcrops only on the northern slopes of the Sistiana Bay in the northeastern block of fault no. IV (30/80) (Fig. 4); however, its fault plane is visible only in the rock-face under the starting point of the Rilke Path (point no. 1). Only the dip direction, and not the dip angle, could be measured (310/?). Further to the east-northeast, the fault plane is identifiable only up to fault no. III. From here and up to fault no. II, the situation is unclear, because the area is covered. On the other side of fault no. II there is a surface 350/80, which is visible in the highway cut and probably belongs to the Sistiana Fault. In the southwestern block of fault no. IV, the Sistiana Fault is displaced in the southeastern direction, but it is covered with tailings of the abandoned quarry. Its extension can be reconstructed after the limestone outcrop on the coast. Fault no. IV and some faults further north, of which two are represented on the map, prove that the Sistiana Fault is segmented. Some faults are positioned transversely and obliquely on the Sistiana Fault. They are visible in the rock-face geometrijskega razmerja med tema dvema enotama $\mathrm{v}$ globini in potrebne podatke za izvajanje modelnih raziskav.

\section{Sesljanski prelom}

Seljanski prelom je na površju viden edino v Sesljanskem zalivu, zato si oglejmo strukturno skico okolice zaliva, ki je prikazana na sl. 3A, njena izdelava temelji na podatkih s Carta geologica del Carso classico italiano (Cucchi \& Piano, 2013) in lastnem orientacijskem ogledu. V območju zaliva so bile potrjene vse bistvene komponente zgradbe: Sesljanski prelom (I), prelom N-S (II) in Tržaški reverzni prelom (III), ki je del narivne zgradbe širšega ozemlja. Med prelomoma št. I in II izdanjata fliš in lapor, bližnje kamnine so kredni, paleocenski in eocenski apnenci. Flišne plasti so prevrnjene.

Sesljanski prelom izdanja le v severnem pobočju Sesljanskega zaliva v severovzhodnem krilu preloma IV (30/80) (sl. 4); vendar je njegovo prelomno ploskev mogoče videti le v steni pod začetnim delom Rilkejeve poti (točka št. 1), kjer pa se da določiti le njeno smer ne pa tudi vpadnega kota (310/?). Naprej proti vzhodu-severovzhodu je trasa določljiva le do preloma št. III. Od tu do preloma št. II so zaradi prekritosti razmere nejasne. Na drugi strani preloma št. II pripada Sesljanskemu prelomu verjetno ploskev 350/80, ki je vidna v useku avtoceste. V jugozahodnem krilu preloma IV je Sesljanski prelom zamaknjen proti jugovzhodu, vendar na površju ni več viden, saj je zasut $\mathrm{z}$ jalovinskim materialom opuščenega kamnoloma. Njegov potek je mogoče rekonstruirati po izdanku apnenca na obali. Prelom IV in nekaj prelomov severno od tega, od katerih sta na sliki 3 vrisana dva, dokazujejo, da je Sesljanski prelom segmentiran. Prelomov, ki ležijo prečno ali poševno na Sesljanskega, je v jugozahodnem krilu preloma IV več; vidni so v steni opuščenega kamnoloma, vendar je njihov odnos do Sesljanskega preloma neznan. Po analogiji bi ga lahko tudi ti sekali, kot je hipotetično prikazano na sliki $3 \mathrm{~A}$. Interpretacija smeri Sesljanskega preloma na tem odseku je povzeta po prvotni morfologiji severozahodnega dela Sesljanskega zaliva, ki je vidna na karti druge izmere Vojaškega zemljevida Habsburške monarhije 1806-1869 na sliki 2B - levo (Historical Maps of the Habsburg Empire. The Second Military Survey 1806-1869). Tu je izrisana prvotna obala zaliva, ki so jo sestavljali kredni, paleocenski in eocenski apnenci pred pričetkom izkoriščanja kamnoloma. Zgradbo in potek obale potrjuje tudi Geološka karta 1:75.000 (Stache, 


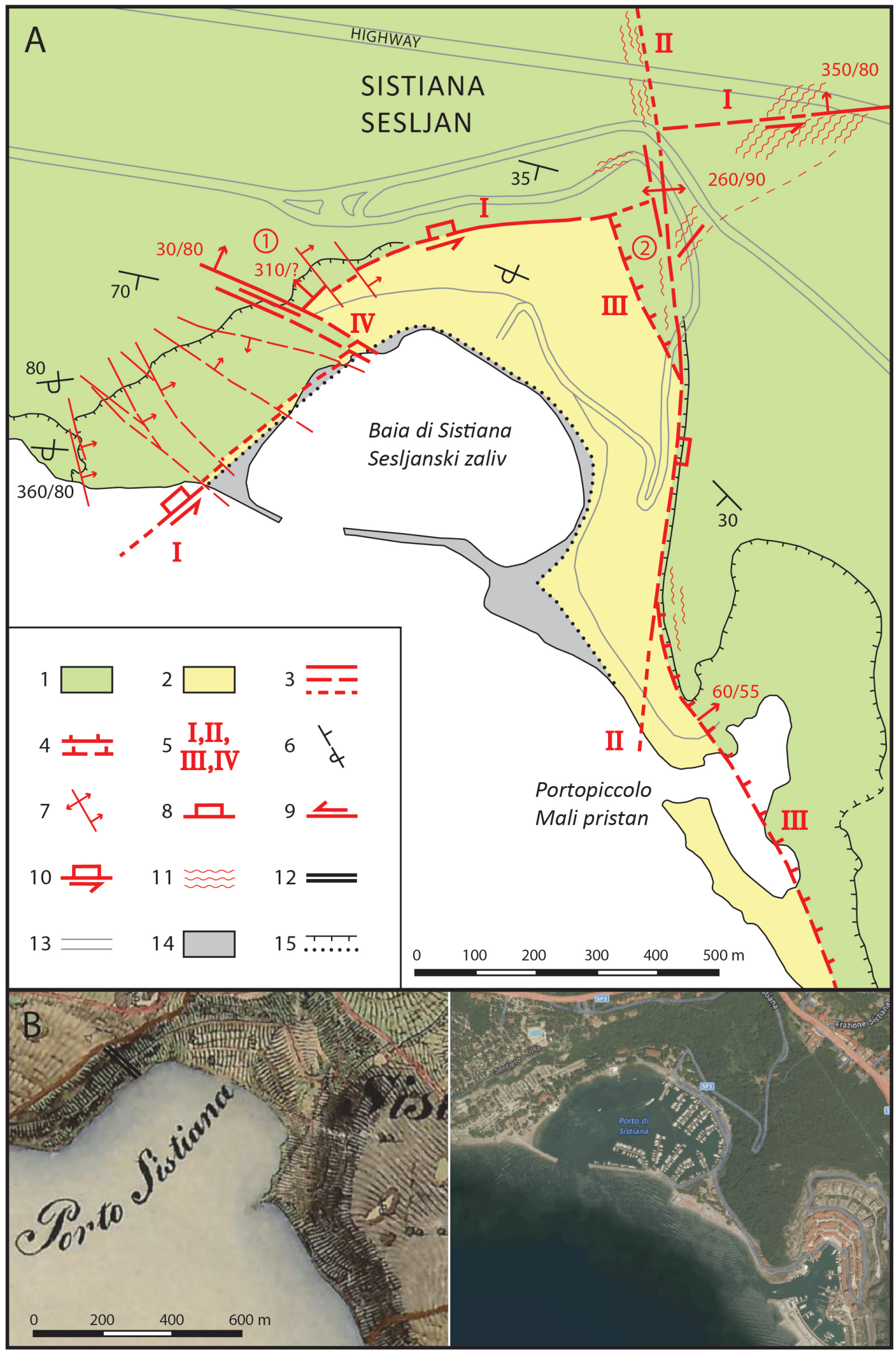

Fig. 3. Sistiana Bay. A. Structural sketch. Amended after Cucchi \& Piano (2013); B. Sistiana Bay: left - Historical Maps of the Habsburg Empire 1806-1869, The Second Military Survey; right - satellite picture, Mapaire.

Sl. 3. Sesljanski zaliv. A. Strukturna skica. Dopolnjeno po Cucchi in Piano (2013); B. Sesljanski zaliv: levo - Vojaški zemljevid Habsburške monarhije 1806-1869, druga izmera; desno - satelitski posnetek, Mapaire. 


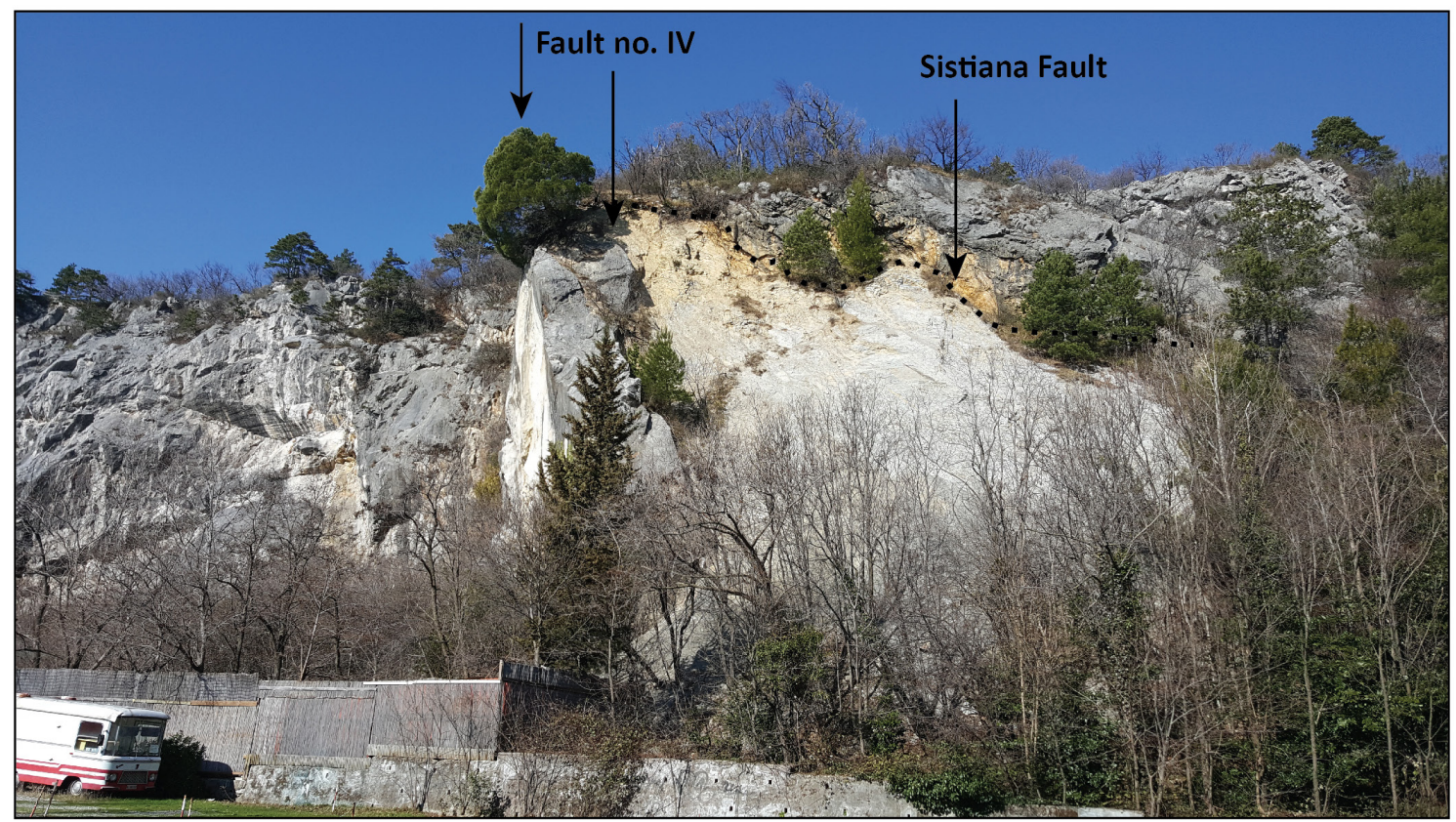

Fig. 4. Sistiana Bay. In the middle of the photo is fault no. IV (30/80), cutting the Sistiana Fault. Left: Cretaceous limestone. Right: Eocene Transitional marlstone, above is a rock face as a fault plane of the Sistiana Fault, behind it is Cretaceous limestone.

Sl. 4. Sesljanski zaliv. Sredi slike je prelom IV (30/80), ki seka Sesljanski prelom. Levo: Kredni apnenec. Desno: eocenski prehodni lapor, nad njim stena kot prelomna ploskev Sesljanskega preloma, zadaj kredni apnenec.

of the abandoned quarry, but their relationship to the Sistiana Fault is unknown. By analogy, they could also cut it, as is hypothetically represented in Fig. 3A. An interpretation of the direction of the Sistiana Fault in this stretch is summarized after the morphology of the northwestern part of Sistiana Bay, as represented in the Historical Maps of the Habsburg Empire. The Second Military Survey 1806-1869 (Fig. 2B - left). The original coast is presented, with Cretaceous, Paleocene, and Eocene limestones before quarrying. The composition and shape of the coast before quarrying is also confirmed in the Geological map 1:75.000
1920), ki je bila izdelana v drugi polovici 19. stoletja, ko tam še ni bilo kamnoloma. Na karti se vidi tudi geološka meja, ki jo danes interpretiramo kot prelom št. IV (30/80).

Na območju točke št. 1 (sl. 3A) so v jugovzhodnem krilu Sesljanskega preloma vidne prehodne plasti, ki pa so priključene flišnim kamninam. Razmere so poenostavljene.

Prelom št. II v smeri N-S je bil določen po morfološkem kriteriju in po izdanku v useku ceste v zaliv (260/90). Prelom št. III je viden v vhodnem delu Malega pristana (Portopiccolo), kjer ima smer 60/55; tu ga spremljajo razpoke v

\section{Fig. 3. / Sl. 3.}

1 Cretaceous and Paleogene limestones / kredni in paleogenski apnenci

2 Eocene Transitional marlstone and Flysch / eocenski prehodni lapor in fliš

3 Important fault: visible, covered or interpolated or extrapolated, uncertain / pomembnejši prelom: viden, prekrit ali interpoliran ali ekstrapoliran, negotovo določen

4 Important reverse fault: visible, covered / pomembnejši reverzni prelom: viden, prekrit

5 Faults: no. I - Sistiana Fault, no. II - N-S fault (260/90), no. III - Trieste reverse fault (60/55), no. IV - sub-vertical fault (30/80) / prelomi: št. I - Sesljanski prelom, št. II - prelom N-S (260/90), št. III - Tržaški reverzni prelom (60/55), št. IV - subvertikalni prelom (30/80)

6 Dip of strata: normal, inverse / plasti: normalne, inverzne

7 Fault planes: vertical, inclined / prelomne ploskve: navpične, poševne

8 Subsided fault block / ugreznjeno krilo preloma

9 Direction of the horizontal component of the displacement along fault / smer horizontalne komponente premika prelomnega krila

10 Combined or oblique displacement of the fault block / kombiniran ali poševen premik prelomnega krila

11 Significant joint zone / pomembnejša razpoklinska cona

12 Fig. B left - location of the contact between Upper Cretaceous and Paleocene limestone after Stache (1920). At this location it is fault no. IV (30/80) in fig. A / sl. B levo, mesto stika zgornjekrednega in paleocenskega apnenca po Stache (1920). Na sl. A je na tem mestu prelom št IV (30/80)

$13 \mathrm{Road} / \mathrm{cesta}$

14 Embankment / nasip

15 Edge of the vertical face; position of the coast between 1806-1869 / rob prepadne stene; obala med letoma 1806-1869 
(Stache, 1920), elaborated in the second half of the $19^{\text {th }}$ century. The geological boundary, now interpreted as fault no. IV (30/80), is well represented.

In the southeastern block of the Sistiana Fault (area of point no. 1 in Fig. 3A) transitional beds incorporated into the flysch are visible. The situation has been simplified.

Fault no. II in the N-S direction was determined according to the morphological criteria and after the outcrop in the roadcut (260/90). Fault no. III is visible in the eastern part of Portopiccolo, with a 60/55 dip, accompanied by joints in the limestone (75/55). Toward the north, up to fault no. II, the fault is determined according to the morphologic step between flysch marlstone and limestone. On the western part of fault no. II, fault no. III is determined after the direction of the western slopes of the valley of the same direction (point no. 2 ), which we believe is formed in the jointed limestone. Fault no. II is part of the joint-fault zone, as reflected in the series of dolines north of the highway. If we compare the displacements of the Sistiana Fault and fault no. III along fault no. II, it is clear that we are looking at two different phases of displacements.

The carbonate strata along Sistiana Bay are positioned in an easterly, Dinaric direction NW-SE; in the northern and northwestern part they divert to the west-east direction, and from their normal position in the north they divert to the overturned position (360/80). In the direction of Duino, they gradually divert again into the normal position. In the hinterland of the Bay, flysch beds appear in an overturned position and dip to the north.

Cucchi \& Piano (2013) considered the Sistiana Fault and fault no. II strike-slip faults, the former with a left-lateral and the latter with a right-lateral displacement. The Sistiana Fault is considered unsegmented, as fault no. II does not cut the first one. Such an interpretation requires at least two strike-slip phases. Our interpretation is slightly different. From the structural sketch (Fig. $3 \mathrm{~A}$ ) it is obvious that a vertical component of the displacement of the block between faults no. I and II larger than the horizontal component. The displacement consisted of a number of components. The displacement of the Sistiana Fault along fault no. II is of secondary origin along the joint-fault zone directed north-south, which part is also fault no. II. Joint-fault zones in this direction are usual in several parts of the Trieste-Komen Anticlinorium. Multiphase displacements are also evidenced by the segmentation of the Sistiana Fault.

From the description above it follows that the origin of the flysch block between the Sistiana apnencu (75/75), proti severu do preloma št. II, pa je določljiv po morfološki stopnji med flišnim laporjem in apnencem. Na zahodni strani preloma št. II je prelom št. III določen po smeri zahodnega pobočja doline enake smeri (sl. 3A, točka št. 2), za katero smatramo, da se je razvila v razpokanem apnencu. Prelom št. II je del razpoklinsko-prelomnega snopa, kar se odraža v nizu kolinearnih vrtač severno od avtoceste. Če vzporejamo premika Sesljanskega preloma in preloma št. III ob prelomu št II, je jasno, da gre za dve različni fazi premikov.

Plasti karbonatnih kamnin okoli Sesljanskega zaliva slemenijo vzhodno od tod pretežno v meri Dinaridov NW-SE, na severni in severozahodni strani pa se iz dinarske obrnejo v smer zahod vzhod in se iz normalne lege proti obali prevrnejo v inverzno lego (360/80). Severno, proti Devinu se plasti polagoma spet obrnejo v normalno lego. Fliš ima v zaledju zaliva inverzno lego ter vpada proti severovzhodu.

Cucchi in Piano (2013) sta Sesljanski prelom in prelom št. II obravnavala kot zmična preloma, prvega kot levi in drugega kot desni zmik. Sesljanski prelom naj bi bil nesegmentiran, prelom št. II pa naj ga ne bi sekal, za kar pa bi bili potrebni vsaj dve fazi premikov. Sedaj predložena interpretacija je nekoliko drugačna. Iz strukturne skice na sliki 3A izhaja, da je imela navpična komponenta premika bloka med prelomoma št. I in št. II večji obseg od vodoravne in da je bilo premikanje večkomponentno. Premik Sesljanskega preloma ob prelomu št. II je sekundarnega izvora, dogodil se je vzdolž razpoklinsko prelomne cone sever-jug, katere del je prelom št. II. Razpoklinsko-prelomne cone te smeri so na območju Tržaško-Komenskega antiklinorija dejavne na več mestih. Večfaznost premikov dokazuje tudi segmentacija Sesljanskega preloma.

Iz napisanega sledi, da je blok flišnih kamnin med Sesljanskim prelomom in prelomom št. II najlažje razložiti z dvigom. To potrjuje tudi pojemanje intenzivnosti Sesljanskega preloma proti vzhodu. Da bi morali ob Sesljanskem prelomu obstajati levozmični premiki izhaja iz njegove regionalne vloge, vendar ima ta komponenta premika v Sesljanskem zalivu sekundarni pomen. Zaradi lažje komunikacije imenujemo blok dvignjenega oziroma vertikalno izrinjenega fliša $v$ zalivu sesljanski izrivni blok.

$\mathrm{V}$ zahodni steni opuščenega kamnoloma $\mathrm{V}$ Sesljanskem zalivu, imajo tektonske drse različne smeri, zdi pa se, da prevladujejo subhorizontalne in subvertikalne. Podobno je v severnem 
Fault and fault no. 2 is best described with the uplift. This also confirms the pinching-out of the Sistiana Fault in the easterly direction. The regional role of the Sistiana Fault infers left lateral strike-slip displacement, although this component of displacement in the Sisitiana Bay is of secondary importance. For the sake the simpler communication, we named this uplifted or vertically erected block the Sistiana Pushout Block.

In the western rock face of the abandoned quarry in the Sistiana Bay, slickensides take different directions, but it appears that sub-horizontal and sub-vertical ones prevail. A similar situation is visible on the northern slopes of the bay and in other areas, which makes the Sistiana Bay a first-class structural-geological object for detailed mapping and structural analysis.

For purposes of this paper, we conclude that the Sistiana Block between the Sistiana Fault and fault no. II is vertically erected and that overturned flysch strata at the bottom of the bay most likely belongs to the footwall block of the reverse fault no. III, which represents the deformed position of the Trieste Thrust.

\section{Sistiana Bending Zone}

\section{General findings}

The more pronounced laterally bent Trieste-Komen Anticlinorium and the less pronounced Vipava Sinclinorium are observable in the Sistiana Bending Zone. The bending axis can be precisely determined only in the Sistiana Bay, while on the northeastern side of the Trieste-Komen Anticlinorium such determinative precision is not possible. We can, with a certain degree of probability, assign its location near Spodnja Branica (Fig. 12). The Vipava Sinclinorium is bent, but there are no adequate structures available to help determine the bending axis. However, what is interesting is the fact that the Idrija Fault is also laterally bent in the continuation of the Sistiana Bay - Spodnja Branica direction. With the position of the boundary between the Trnovo and Hrušica Nappes, we can suggest a modification of the original relationship between thrust-units. Based on the Sistiana Bay - Spodnja Branica line, the approximate axis direction of the Sistiana Bending Zone is $60^{\circ}-65^{\circ}$. The bending axis is not represented as a line, but rather as an area of tolerance seen as a circular section with an angle of about $5^{\circ}$ (Fig. 5).

The size of the angle of the lateral bending of individual structural units in the Sistiana Bending Zone can be determined only approximately, pobočju zaliva in drugod, zato je Sesljanski zaliv prvovrstni strukturno-geološki objekt za detajlno kartiranje in strukturno analizo.

Za potrebe tega članka zadostuje ugotovitev, da je sesljanski blok med Sesljanskim prelomom in prelomom št. II izrinjen navzgor in da inverzija flišnih plasti v dnu zaliva najverjetneje kaže na to, da pripada talninski grudi reverznega preloma št III, ki predstavlja deformirano lego Tržaškega nariva.

\section{Sesljanska upogibna cona}

\section{Splošne ugotovitve}

$\mathrm{V}$ sesljanski upogibni coni sta vidno bočno upognjena Tržaško-komenski antiklinorij in Vipavski sinklinorij; prvi bolj, drugi nekoliko manj. Os upogiba je mogoče natančno določiti le v Sesljanskem zalivu, kjer se sprememba smeri plasti dogodi vzdolž prelomne ploskve Sesljanskega preloma, na severovzhodni strani Tržaško-Komenskega antiklinorija pa taka natančnost ni mogoča, lahko pa s precejšnjo mero gotovosti ugotovimo, da se nahaja blizu Spodnje Branice (sl. 12). Vipavski sinklinorij je upognjen, toda za določanje osi upogiba ni na voljo ustreznih struktur, preseneča pa dejstvo, da je v podaljšku smeri Sesljanski zaliv - Spodnja Branica bočno usločen tudi Idrijski prelom. Po legi meje med Trnovskim in Hrušiškim pokrovom je mogoče domnevati, da je spremenjen tudi prvotni odnos med omenjenima krovnima enotama. Glede na črto Sesljanski zaliv - Spodnja Branica, znaša približna smer osi sesljanske upogibne cone $60^{\circ}$ do $65^{\circ}$. Na sliki 5 ni izrisana os upogiba temveč območje njene tolerančne lege, zato je sesljanska upogibna cona prikazana kot krožni izsek s kotom okoli $5^{\circ}$.

Velikost kota bočnega upogiba posameznih strukturnih enot $\mathrm{v}$ sesljanski upogibni coni je mogoče določiti le približno, kar pa ne moti, saj stopnja natančnosti podatka ne vpliva na končno interpretacijo (sl. 5). V Sesljanskem zalivu ga je mogoče določiti po legi plasti, kjer znaša okoli $20^{\circ}$. Za Tržaško-Komenski antiklinorij je kot upogiba najlaže določiti iz slemenitve Kraške grupe formacij (Jurkovšek et al., 2013) plasti v severovzhodnem krilu antiklinorija $\left(\mathrm{a}_{1}, \mathrm{a}_{2}\right)$ in izven vpliva Raškega preloma. Ta znaša približno $18^{\circ}$. Iz slike 5 izhaja, da ima velikost kota $\mathrm{v}$ Sesljanskem zalivu le ožji pomen, zato je za izhodiščno vrednost najbolje vzeti podatek o upogibu celotnega antiklinorija, torej $18^{\circ}$. Velikost upogiba osi Vipavskega sinklinorija je težko določiti, ker je deformirana zaradi izpostavljene 


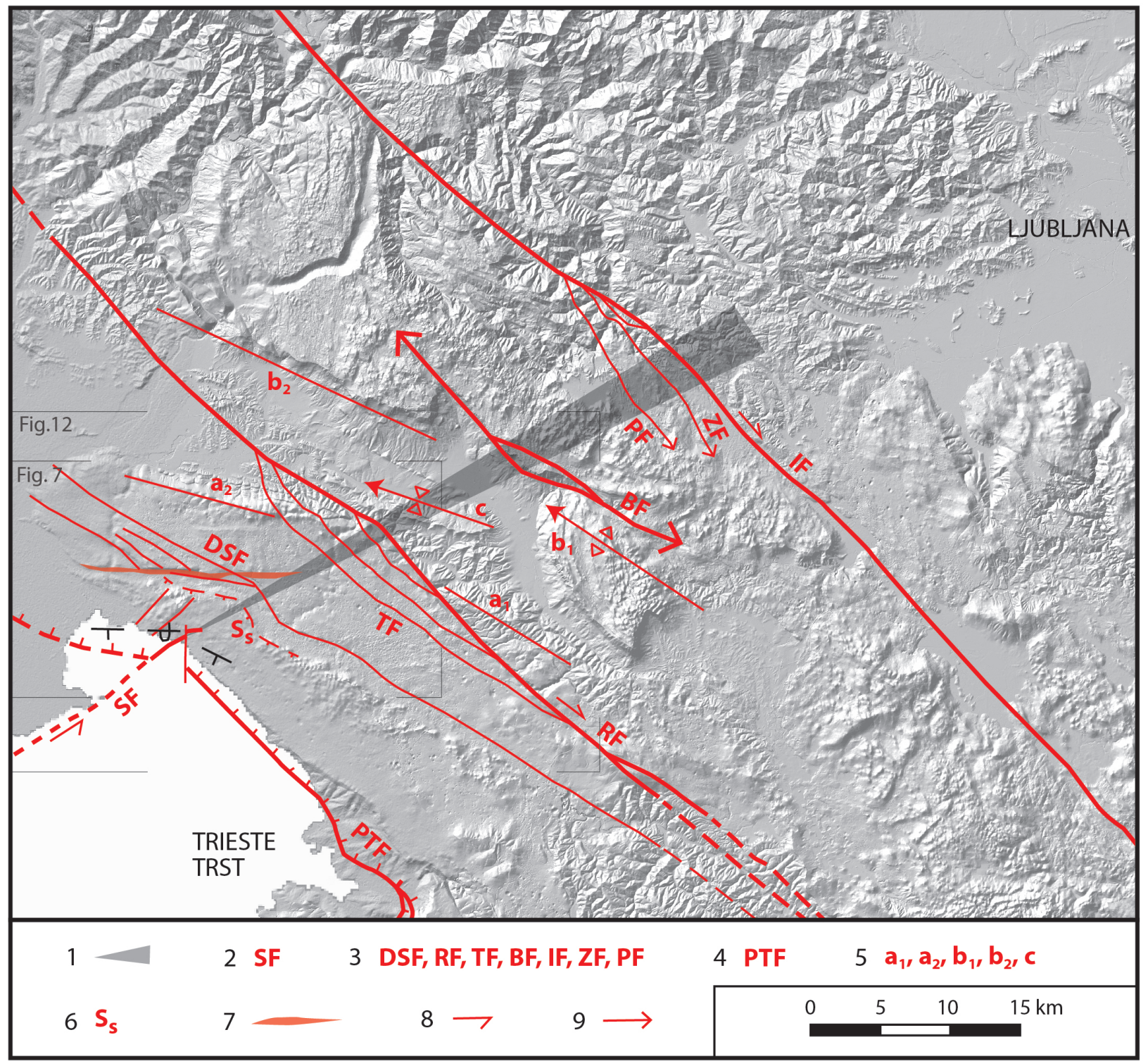

Fig. 5. Sistiana Bending Zone.

Sl. 5. Sesljanska upogibna cona.

1 Sistiana Bending Zone / sesljanska upogibna cona

$2 \mathrm{SF}$ - Sistiana Fault / Sesljanski prelom

3 Faults in direction of Dinarides / dinarsko usmerjeni prelomi: DSF - Divača splay of faults / Divaški snop prelomov, RF Raša Fault / Raški prelom, TF - Tomačevica Fault / Tomačevski prelom, BF - Bela Fault / Belski prelom, IF - Idrija Fault / Idrijski prelom / ZF - Zala Fault / Zalin prelom, PF - Predgriže Fault / Predgriški prelom

4 PTF - Palmanova Thrust Fault / Palmanovski narivni prelom

5 Rotating structures / zasukane strukture: $\mathrm{a}_{1}, \mathrm{a}_{2}$ - Direction of the Trieste-Komen Anticlinorium / smer Tržaško-Komenskega antiklinorija, b1 - Nanos Anticline in the Hrušica Nappe thrust-front / smer Nanoške antiklinale v čelu Hrušiškega pokrova, $b_{2}$ - Direction of the Trnovo Nappe thrust-front / smer čela Trnovskega pokrova, c - Planina Syncline in the Vipava Synclinorium / smer Planinske sinklinale v Vipavskem sinklinoriju

6 Ss - Sistiana Sigmoid, dip of strata / sesljanska sigmoida, vpad plasti

7 Komen Wedge Structural Step / komenski klinasti strukturni prag

8 Relative direction of displacement / relativna smer premika

9 Continuation of the fault, no detailed geological mapping performed / prelom se nadaljuje, ni podrobno geološko kartirano

but this is not of particular importance, because the degree of accuracy of the data does not affect the final interpretation (Fig. 5). In Sistiana Bay, it can be determined after the position of the strata, which amounts to approximately $20^{\circ}$. In the Trieste-Komen Anticlinorium, a bending axis of approx. $18^{\circ}$ can be determined from the strike lege Nanosa v čelnem delu Hrušiškega pokrova, je pa gotovo manjša od upogiba Tržaško-Komenskega antiklinorija. Naprej proti severovzhodu sprememba smeri v nakazani smeri ni več tako očitna, vendar obstajajo, saj je bilo že rečeno, da je v širokem loku ukrivljena tudi trasa Idrijskega preloma. Če je tako, bi morala biti eden nasproti 
direction of the Kras Group Formation (Jurkovšek et. al., 2013) in the northeastern limb of the anticlinorium $\left(\mathrm{a}_{1}, \mathrm{a}_{2}\right)$, and outside the influence of the Raša Fault. Based on the Fig. 5, the amount of the angle in Sistiana Bay has only minor influence, consequently we took $18^{\circ}$ as a base value. The size of the bending of the axis of the Vipava Sinclinorium is difficult to determine because of the exposed position of Nanos in the thrust-front of the Hrušica Nappe. It is certainly smaller, compared to the bending of the Trieste-Komen Anticlinorium. Further to the northeast, the change in direction in the indicated continuation is not so obvious, but does exist, since it has already been said that the line of the Idrija Fault is also curved in a wide arc. If this assumption is correct, the Trnovo and Hrušica Nappes also need to be rotated against each other. The amount of the angle of eventual rotation between the two thrust units is difficult to determine, but some general information can be determined. The direction of the thrust-unit is generally determinable by the direction of the dominant slickensides in the principal thrust plane, which are perpendicular to the strike direction of the thrust unit, and by the position of the folds axis formed during the thrusting. In both cases, owing to the inhomogeneity of the thrust units and consequent oscillations in displacement directions the data is only statistical. Under the given conditions, the direction of the Nanos Anticline axis $\left(b_{1}\right)$ in the Hrušica Nappe can be determined, while no such information is available for the Trnovo Nappe, but it is possible to approximate the direction of the thrust front $\left(b_{2}\right)$, which is not possible at Nanos, because the thrust front is not reliably fixed. Therefore, both figures were used for orientation. The axis of the frontal anticline of the Hrušica Nappe dip in the northwestern direction (304/23) (Placer, 1981, Fig. 1). The thrust-front of the Trnovo Nappe strikes approx. in the $295^{\circ}$ direction. Although the data does not represent a reliable starting point, it is nevertheless interesting that the $9^{\circ}$ direction obtained is consistent with the decreasing angle of arch of the Sistiana Bending Zone to the northeast. The Trnovo Nappe should therefore be rotated counterclockwise, just like the rest of the blocks northwest of the Sistiana Bending Zone. The direction of the dominant slickensides in the Planina Quarry (Placer, 1994/95, Fig. 6) was not considered, since it is too far from the thrust front of the Hrušica Nappe and does not represent the statistical average.

Clear evidence of a decrease in lateral bending from the southwest to the northeast is seen in drugemu zasukana tudi Trnovski in Hrušiški pokrov. Velikost kota morebitnega zasuka med omenjenima krovnima enotama je težko določljiva, mogoče pa je dati splošno informacijo. Smer krovne enote je na splošno določljiva po smeri dominantnih tektonskih drs v glavni narivni ploskvi, ki ležijo pravokotno na smer narivne enote in po legi osi gub, ki so nastale med narivanjem. V obeh primerih je podatek lahko le statističen, saj so narivne enote nehomogene, zaradi česar do določene mere niha tudi smer premikov. V danih razmerah je pri Hrušiškem pokrovu mogoče določiti smer osi Nanoške antiklinale $\left(b_{1}\right)$, medtem ko pri Trnovskem pokrovu takega podatka ni, vendar je mogoče približno izmeriti smer čela krovnega nariva $\left(b_{2}\right)$, česar pri Nanosu ni mogoče, ker čelo nariva ni zanesljivo določeno. Zato sta bila za orientacijo uporabljena omenjena podatka. Os čelne antiklinale Hrušiškega pokrova vpada proti severozahodu 304/23 (Placer, 1981, sl. 1), čelo Trnovskega pokrova poteka približno v smeri $295^{\circ}$. Čeprav podatka ne predstavljata zanesljivega izhodišča, je vseeno zanimivo, da je dobljena razlika $\mathrm{v}$ smereh, $9^{\circ}$ skladna $\mathrm{z}$ manjšanjem kota usločitve sesljanske upogibne cone proti severovzhodu. Trnovski pokrov naj bi torej bil zasukan v nasprotni smeri urinega kazalca tako kot ostali bloki severozahodno od sesljanske upogibne cone. Smer dominantnih drs v kamnolomu pri Planini (Placer, 1994/95, sl. 6 ) ni bila upoštevana, ker je kraj preveč oddaljen od čela Hrušiškega pokrova in ne predstavlja statističnega povprečja.

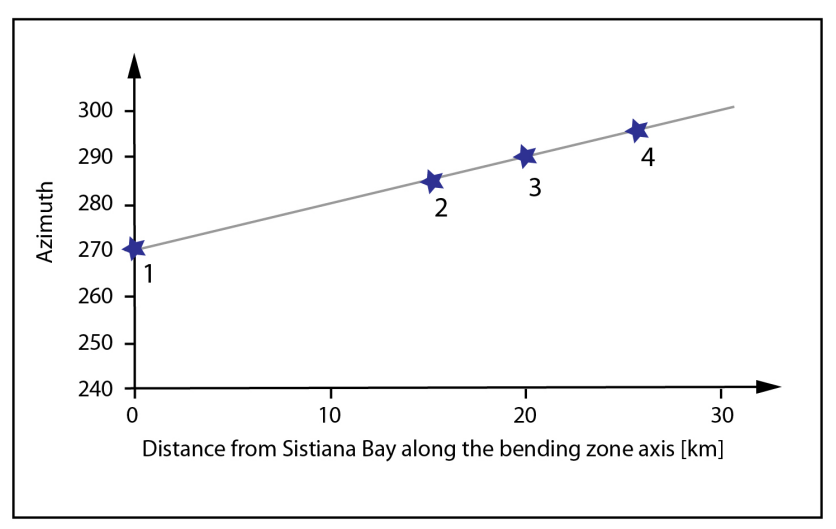

Fig. 6. Diagram of external rotation of the structural units of the northeastern wing of the Sistiana Bending Zone.

Sl. 6. Diagram eksterne rotacije strukturnih enot severozahodnega krila sesljanske upogibne cone.

1 Sistiana Bay (bedding strike) / Sesljanski zaliv (smer plasti) $2 \mathrm{a}_{2}$ - Northern edge of the Trieste-Komen Anticlinorium / severni rob Tržaško-Komenskega antiklinorija

$3 \mathrm{c}-$ Axis of the Planina Syncline is identical with the direction of the Vipava Synclinorium / os Planinske sinklinale je identična s smerjo Vipavskega sinklinorija

$4 \mathrm{~b}_{2}$ - Trnovo Nappe thrust-front / čelo Trnovskega pokrova 
the change in the azimuth of those structures in the northwestern wing of the Sistiana Bending Zone, which was originally oriented in the Dinaric direction (Fig. 6). The strike of bedding in the Sistiana Bay is approx. $270^{\circ}$ (point 1), and in the Liburnian Formation in the northeastern limb of the Trieste-Komen Anticlinorium approx. $285^{\circ}$ ( $\mathrm{a}_{2}$, point 2), while the azimuth of the axis of the northwestern and central part of the Vipava Synclinorium, as determined by the axis of the syncline from the flysch calcarenites, and breccias in the Planina area, is approximately $290^{\circ}$ (c, point 3 ), and the strike of the front of the Trnovo Nappe is $295^{\circ}\left(b_{2}\right.$, point 4$)$. The linear relationship between the points indicates the corresponding order.

The syncline with flysch calcarenites, and breccias in the Planina area on the axis of the Vipava Synclinorium (Planina Syncline) is purely horizontally rotated, together with the northwestern limb of the synclinorium, although it does extend beyond the axis of the Sistiana Bending Zone. The horizon of calcarenites, and breccias is over 100 $\mathrm{m}$ thick and represents a weakly ductile unit in flysch rocks of high ductility. It did not bend in the flexural zone, but twisted rigidly. This was possible because the axis of the Planina syncline dips in the west-northwest direction and the bulk of its mass is positioned in the rotating wing of the bending zone. As this paper is dedicated to the regional importance of the Sistiana Bending Zone we have only raised the issue of the "anomalous position" of the clastites in the Planina Syncline. Differences in rock ductility play an important role in the structural and geomorphological analysis of the Istra Pushed Area.

\section{Deformation of the faults in the Dinaric direction}

In addition to the units described during the period of thrusting (the Trieste-Komen Anticlinorium, the Vipava Synclinorium, and the Trnovo and Hrušica Nappe), the Dinaric-directed faults are also important: the Paleodivača, Raša, Belsko (Placer et al., 2021) and Idrija faults. The Paleodivača Fault represents the primary structure of the Divača Splay Faults (Fig. 7). Both terms in this article are mentioned in the geological literature for the first time, but we address them only to the extent that it is necessary for a complete presentation of the Sistiana Bending Zone.

All faults are bent in the Sistiana Bending Zone, except that their bending angles are different. The Paleodivača and Idrija faults are bent as much as their bearing units, in the first case the Trieste-Komen Anticlinorium, and in the second, the Trnovo Nappe opposite the Hrušica
Nazoren dokaz manjšanja bočnega upogiba od jugozahoda proti severovzhodu daje sprememba azimuta tistih struktur v severozahodnem krilu sesljanske upogibne cone, ki so prvotno imele dinarsko smer (sl. 6). Azimut slemenitve plasti v Sesljanskem zalivu znaša okoli $270^{\circ}$ (točka 1 ), liburnijskih plasti $\mathrm{v}$ severovzhodnem krilu tržaško-komenske antiforme znaša okoli $285^{\circ}\left(\mathrm{a}_{2}\right.$, točka 2), azimut osi severozahodnega in osrednjega dela Vipavskega sinklinorija, ki ga določa os sinklinale iz flišnih apnenih peščenjakov in breč na območju Planine, znaša približno $290^{\circ}$ (c, točka 3), azimut smeri čela Trnovskega pokrova znaša $295^{\circ}\left(b_{2}\right.$ točka 4$)$. Linearen odnos med točkami kaže na ustrezno zakonitost.

Sinklinala flišnih apnenih peščenjakov in breč na območju Planine v osi Vipavskega sinklinorija (Planinska sinklinala) je v celoti horizontalno zasukana skupaj s severozahodnim krilom sinklinorija, čeprav sega preko osi sesljanske upogibne cone. Paket apnenčevih peščenjakov in breč je v najmočnejšem delu debel več $100 \mathrm{~m}$ in predstavlja vložek slabo duktilne kamninske mase $\mathrm{v}$ flišnih plasteh visoke duktilnosti. $\mathrm{V}$ upogibni coni se ni usločil temveč togo zasukal. To je bilo mogoče zato, ker vpada os Planinske sinklinale proti zahodu-severozahodu in leži pretežni del njegove mase v zasukanem krilu upogibne cone. Ta prispevek je posvečen regionalnemu pomenu sesljanske upogibne cone, zato smo na vprašanje »anomalne lege« paketa debelozrnatih flišnih klastitov v Planinski sinklinali le opozorili. Razlike v duktilnosti kamnin imajo pomembno vlogo v strukturni in geomorfološki analizi istrskega potisnega območja.

\section{Deformacije prelomov dinarske smeri}

Poleg opisanih enot, ki so nastale v obdobju narivanja (Tržaško-Komenski antiklinorij in Vipavski sinklinorij ter Trnovski in Hrušiški pokrov), so pomemben označevalec upogiba tudi dinarsko usmerjeni prelomi: Paleodivaški, Raški, Belski (Placer in sodelavci, 2021) in Idrijski prelom. Paleodivaški prelom predstavlja primarno strukturo divaškega snopa prelomov (sl. 7). Oba pojma sta $\mathrm{v}$ tem članku prvič omenjena $\mathrm{v}$ geološki literaturi, vendar ju obravnavamo le toliko, kolikor je potrebno za celovito predstavitev sesljanske upogibne cone.

Vsi omenjeni prelomi so v sesljanski upogibni coni upognjeni, le da je njihov kot upogiba različen. Paleodivaški in Idrijski prelom sta upognjena toliko kot njuni nosilni enoti, v prvem primeru Tržaško-Komenski antiklinorij, v drugem Trnovski pokrov nasproti Hrušiškemu. Raški 


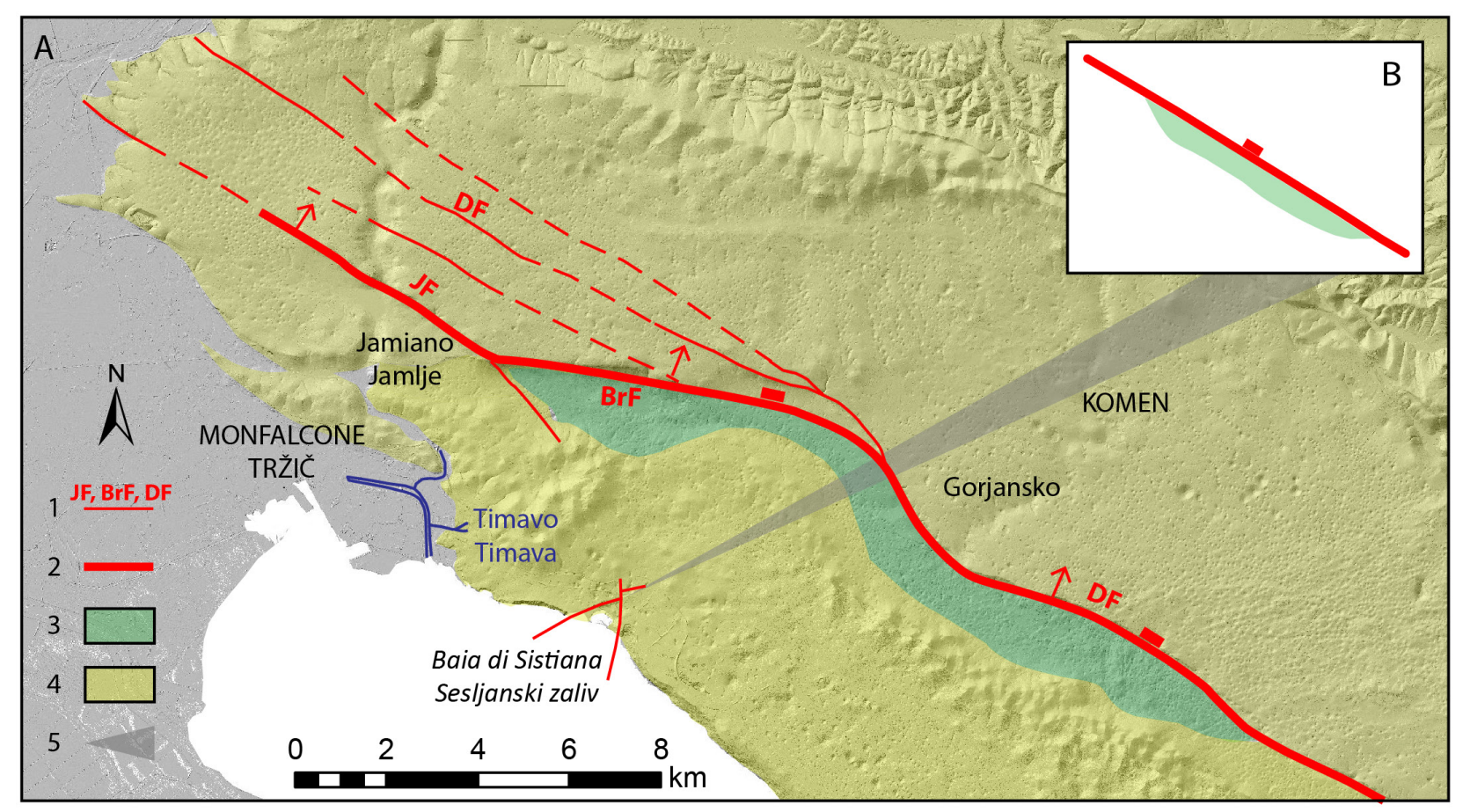

Fig. 7. Paleodivača Fault. Geological bases after Jurkovšek (2010). A. Recent structure. Divača splay of faults; B. Undeformed primary position of the Paleodivača Fault.

S1. 7. Paleodivaški prelom. Geološka osnova po Jurkovšek (2010). A. Sedanja zgradba.Divaški snop prelomov; B. Nedeformirana prvotna lega Paleodivaškega preloma.

1 Divača splay of faults / divaški snop prelomov: JF - Jamiano Fault / Jameljski prelom, BrF - Brestovica Fault / Brestoviški prelom, DF - Divača Fault / Divaški prelom

2 Paleodivača Fault, recent structure / Paleodivaški prelom, sedanja lega

3 Brje Formation (Early Cretaceous), the oldest unit of the Trieste-Komen Anticlinorium / Brska formacija spodnjekredne starosti. Najstarejše plasti Tržaško-Komenskega antiklinorija

4 Povir Formation and younger units (Late Cretaceous, Paleocene and Eocene) / Povirska formacija in mlajše plasti zgornjekredne, paleocenske in eocenske starosti

5 Sistiana Bending Zone / sesljanska upogibna cona

Nappe. The Raša Fault is less bent than the Trieste-Komen Anticlinorium and the Vipava Synclinorium. The relationship in the Belsko Fault is different because it is related to the deformation of Nanos, but an interpretation of this case would require special discussion, so it is not discussed further here.

The term Divača Fault Splay is based on the data of the Geological map of the Northern part of the Trieste-Komen Plateau 1: 25,000 (Jurkovšek, 2010; Jurkovšek et al., 2013), where a group of dislocations accompany the Divača Fault. Their genesis has been linked to several kinematic phases, which are not the subject of this article. Only the initial formation of the splay, whose central element was the Paleodivača Fault, is relevant. Figure 7A depicts the current shape of the splay, consisting of the Divača Fault, the Brestovica Fault, the Jamiano Fault, the faults between the Divača and Jamiano faults that lean on the Brestovica Fault, and the accompanying faults that extend to the Divača Fault in its northeastern block. prelom je upognjen manj od Tržaško-Komenskega antiklinorija in Vipavskega sinklinorija. Pri Belskem prelomu je odnos drugačen, ker je povezan $\mathrm{z}$ deformacijo Nanosa, vendar bi razlaga tega primera zahtevala posebno razpravo, zato ga puščamo ob strani.

Termin divaški snop prelomov je postavljen na podlagi podatkov Geološke karte severnega dela Tržaško-Komenske planote 1: 25.000 (Jurkovšek, 2010; Jurkovšek in sodelavci, 2013), po kateri spremlja Divaški prelom skupina dislokacij. Njihova geneza je bila povezana $z$ več kinematskimi fazami, kar pa ni predmet tega članka, pomembna je le izhodiščna oblika snopa, katere središčni element je bil Paleodivaški prelom. Na sliki 7A je narisana današnja oblika snopa, ki ga sestavljajo Divaški prelom, Brestoviški prelom, Jameljski prelom, prelomi med Divaškim in Jameljskim prelomom, ki se naslanjajo na Brestoviški prelom, in prelomi, ki spremljajo Divaškega v njegovem severovzhodnem krilu. Trase vseh teh so jasno vidne na digitalnem modelu reliefa iz lidarskih 
Traces of all these faults are clearly visible on the digital terrain model based on lidar data. The Paleodivača Fault is now deformed in the splay and connects the Divača Fault branch southeast of Gorjansko, the Brestovica Fault, and the Jamiano Fault branch northwest of Jamlje. During the formation, the fault plane was straight (Fig. 7B) and its north block was subsided, so that the units of the Brje Formation in the southern block met the units of the Sežana Formation in the northern block. The originally straight surface of the Paleodivača Fault is today bent in the Sistiana Bending Zone, together with the Trieste-Komen Anticlinorium.

The bending of the Paleodivača Fault is equal to the bending of the Trieste-Komen Anticlinorium. The Raša Fault cuts the northeastern part of the Trieste-Komen Anticlinorium and the western part of the Vipava Synclinorium (Figs. 2 and 5). If we ignore its genesis and look only at its relation to the Sistiana Bending Zone, three peculiarities are important:

1. In the Sistiana Bending Zone, the fault line is curved, but not as pronounced as the Trieste-Komen Anticlinorium.

2. Shear lenses, which are bounded by the Tomačevica, Kobjeglava, and Lukovica faults, along with some minor ones (Figs. 5 and $8 \mathrm{~A}$ ), are present in the bending zone. We can conclude that the three faults were formed due to the tendency to straighten the curved shear plane of the Raša Fault.

3. The Tomačevica, Kobjeglava, and Lukovica faults are also bent in the Sistiana Bending Zone, but the bending is not so pronounced, so it can only be considered an assumption.

The Tomačevica, Kobjeglava, and Lukovica faults represent secondary faults that are arranged in a series of strike-slip duplexes. Their peculiarity is that they were not formed according to the standard models of the development of the fault zone, but after lateral bending of the strike-slip fault plane. During the subsequent strike-slip, the resistance due to the bulge of the bent surface is counterbalanced by the formation of one or more faults forming one or more fault lenses with the principal fault plane. The resulting faults reflect the tendency to flatten the shear plane or zone, so it is more appropriate to name them in more detail. The terms fault splay, shear lenses, bend, strike-slip duplex, linkage duplex, flower structure, sidewall ripout, and ripout structure are used in the literature for the sake of similar fault geometry terminology (Swanson, 2005; Cunningham \& Mann, 2007), but none of the podatkov. Paleodivaški prelom je v snopu danes deformiran in povezuje krak Divaškega preloma jugovzhodno od Gorjanskega, Brestoviški prelom in krak Jameljskega preloma severozahodno od Jamelj. Ob nastanku je bila obravnavana prelomna ploskev ravna (sl. 7B), njeno severno krilo je bilo ugreznjeno, tako da so prišle v stik kamnine Brske formacije v južnem krilu s kamninami Sežanske formacije v severnem krilu. Prvotno ravna ploskev Paleodivaškega preloma je danes upognjena v sesljanski upogibni coni skupaj s Tržaško-Komenskim antiklinorijem.

Upogib Paleodivaškega preloma je enak upogibu Tržaško-Komenskega antiklinorija.

Raški prelom seka severovzhodni del Tržaško-Komenskega antiklinorija in zahodni del Vipavskega sinklinorija (sl. 2 in 5). Č zanemarimo njegovo genezo in si ogledamo le njegov odnos do sesljanske upogibne cone, izstopajo tri posebnosti:

1. V sesljanski upogibni coni je trasa preloma ukrivljena, vendar ne tako močno kot Tržaško-Komenski antiklinorij.

2. V območju upogiba nastopajo prelomne leče, ki jih omejujejo Tomačevski, Kobjeglavski in Lukovški prelom ter nekaj manjših (sl. 5 in 8A). Iz tega izhaja sklep, da so omenjeni trije prelomi nastali zaradi težnje po izravnavi ukrivljene strižne ploskve Raškega preloma.

3. V Sesljanski upogibni coni so enako upognjeni tudi Tomačevski, Kobjeglavski in Lukovški prelom, vendar upognjenost ni izrazita, zato jo je moč obravnavati le kot domnevo.

Tomačevski, Kobjeglavski in Lukovški prelom predstavljajo sekundarne prelome, ki so razporejeni v niz strižnih dupleksov. Izstopajo po tem, da niso nastali po standardnih modelih razvoja prelomne cone, temveč po bočnem upogibu zmične prelomne ploskve. Pri ponovnem zmikanju se upor zaradi grbine upognjene prelomne ploskve uravna z nastankom enega ali več novih prelomov, ki tvorijo z glavno prelomno ploskvijo eno ali več prelomnih leč. Nastali prelomi so odraz težnje po izravnavi strižne ploskve ali cone, zato jih je smiselno določneje poimenovati. V literaturi se za po videzu podobno geometrijo prelomov uporabljajo izrazi snop prelomov (fault splay), strižne leče (shear lenses), prevoj (bend), zmični dupleks (strike-slip duplex), povezovalni dupleks (linkage duplex), pahljačasta struktura (flower structure), stranski izriv (sidewall ripout) in izrivna struktura (ripout structure) (Swanson, 2005; Cunningham in Mann, 2007), vendar nobeden od teh izrazov in pojavov, ki jih opisujejo, ne definira opisanega primera sekundarnih prelomov 
terms and the phenomena they describe define the presented example of secondary faults along the Raša Fault. Therefore, we propose a new term, adjusting faults, and for the structure itself, adjusting structure. The relation of the adjusting faults to the principal fault deep in the vertical plane of the axis of the bending zone cannot be discussed without proper laboratory modeling.

The Tomačevica Fault leans asymmetrically toward the Raša Fault trace with respect to the bending zone; in the northwest the leaning angle is larger (splitting side), in the southeast it is smaller (connecting side). We assume that the difference is a result of the geometry of the stress in the bending zone, which is derived from the position of the adjusting fault (Fig. 8B). This characteristic appears in the Tomačevica Fault because it is positioned on the external boundary of the adjusting fault, while the same is not as obvious for the other two faults. This is probably because of the secondary effects, which could be inferred from the complex situation inside the Lukovica strike slip lens and slightly less inside the Kobjeglava strike slip lens. It follows that the Lukovica Fault probably formed first, then the Kobjeglava Fault, and finally the Tomačevica Fault. In contrast to the two lenses between the Tomačevica and Lukovica faults, the splitting part of the lens between the Lukovica and Raša faults is subsided, while the connecting side is uplifted, indicating the effects of dexral strike slip divergence and convergence. This feature is pronouncedly developed only in this case, which again indicates that the Lukovica adjusting fault is the oldest of the three (Fig. 8A). The regional kinematics of the Raša Fault is discussed in another article.

The example in Figure $8 \mathrm{~B}$ shows the initial phase of the formation of the adjusting fault, with further dextral strike slip activity, dextral strike slip divergence and convergence develop, and in the final phase, the tectonic lens is included in the wider fault zone of the main fault. The development of this process beyond the scope of this article.

In the literature, there is no data to support laboratory modeling for the study of adjusting faults, so we propose a design for a method to conduct an experiment (Fig. 8C).

In the area between Dornberk and Ilirska Bistrica (about $50 \mathrm{~km}$ ) there is evidence of dextral strike slip and vertical component of movement along the Raška fault; however, the relationship between individual components and lateral bending is not the subject of this article. ob Raškem prelomu. Zato zanje predlagamo nov termin izravnalni prelomi (adjusting faults), za samo zgradbo pa izravnalna zgradba (adjusting structure). O odnosu izravnalnih prelomov do glavnega preloma v globini v vertikalni ravnini osi upogibne cone, ne moremo razpravljati brez laboratorijskih preizkusov.

Tomačevski prelom se glede na upogibno cono asimetrično naslanja na traso Raškega preloma; na severozahodu je kot priključka večji (odcepilna stran), na jugovzhodu je kot manjši (priključna stran). Domnevamo, da je razlika posledica geometrije napetostnega stanja v območju upogiba, ki je izpeljana iz lege izravnalnega preloma (sl. 8B). Ta značilnost izstopa pri Tomačevskem prelomu, ker leži na zunanji meji izravnalnega snopa, medtem ko pri ostalih dveh ni tako očitna. Verjetno zaradi drugotnih vplivov, na kar bi bilo mogoče sklepati po zapletenih razmerah znotraj lukovške zmične leče in nekoliko manj znotraj kobjeglavske. Iz tega sledi, da je verjetno najprej nastal Lukovški, nato Kobjeglavski in nazadnje Tomačevski prelom. V nasprotju z lečama med Tomačevskim in Kobjeglavskim ter Kobjeglavskim in Lukovškim prelomom je odcepilna stran leče med Lukovškim in Raškim prelomom ugreznjena, priključna pa dvignjena, oboje kaže na učinek desnozmične divergence in konvergence. Pojav je izraziteje razvit le v tem primeru, kar ponovno kaže na to, da je Lukovški izravnalni prelom najstarejši (sl. 8A). O regionalni kinematiki Raškega preloma bo tekla razprava v drugem članku.

Primer na sliki 8B prikazuje inicialno fazo nastanka izravnalnega preloma, pri nadaljnjem desnem zmikanju se razvijeta desnozmična divergenca in konvergenca, $v$ končni fazi pa se obprelomna leča vključi v širšo prelomno cono vodilnega preloma. Razvoj tega procesa ne sodi v okvir pričujočega članka.

V literaturi ni podatkov o usmerjenih laboratorijskih preizkusih o nastanku izravnalnih prelomov, zato podajamo predlog izdelave preizkusnega vzorca in način izvedbe eksperimenta (sl. 8C).

$\mathrm{Na}$ prostoru med Dornberkom in Ilirsko Bistrico (okoli $50 \mathrm{~km}$ ) obstajajo dokazi za desnozmično in vertikalno komponento premika ob Raškem prelomu. Razmerje med posameznimi komponentami in bočnim upogibanjem ni predmet tega članka.

Pri interpretaciji izravnalne zgradbe Raškega preloma, se postavlja zanimivo vprašanje nastanka spremljajočih prelomov Idrijskega preloma kot so prikazani na Geološki karti 


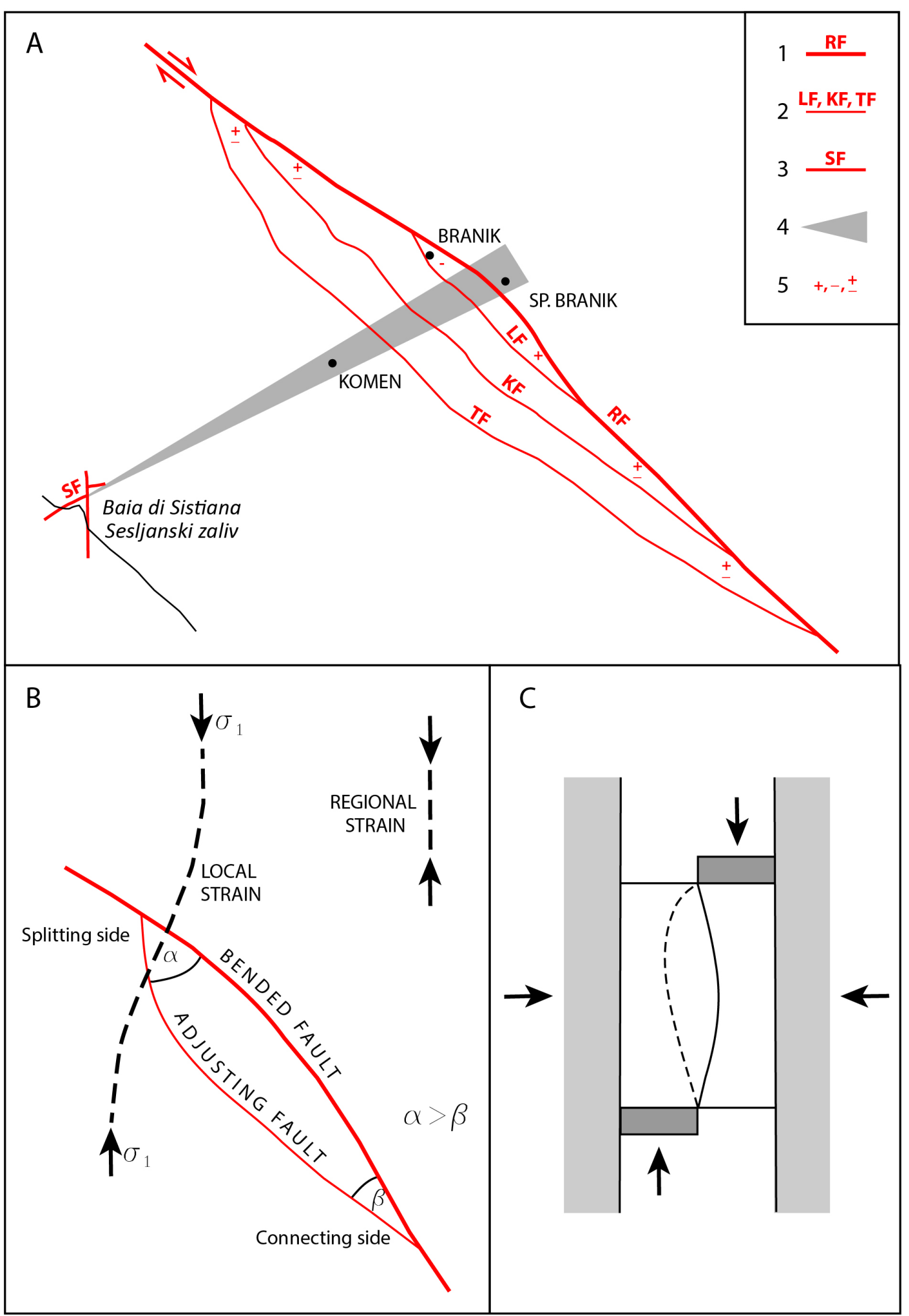

Fig. 8. Origin of the adjusting faults. A. Adjusting structure of the Raša Fault. Geological bases after Jurkovšek (2010) and Placer (2015); B. Dynamic model, initial phase; C. Laboratory modeling proposal.

S1. 8. Nastanek izravnalnih prelomov. A. Izravnalna zgradba Raškega preloma. Geologija po Jurkovšek (2010), Placer (2015); B. Dinamski model, inicialna faza; C. Predlog laboratorijskega preizkusa.

1 Raša Fault / Raški prelom

2 Adjusting structure of the Raša Fault, adjusting faults / izravnalna zgradba Raškega preloma, izravnalni prelomi: TF Tomačevica Fault / Tomačevski prelom, KF - Kobjeglava Fault / Kobjeglavski prelom, LF - Lukovica Fault / Lukovški prelom $3 \mathrm{SF}$ - Sistiana Fault / Sesljanski prelom

4 Sistiana Bending Zone / sesljanska upogibna cona

5 Uplift, subsidence, negligible vertical displacement / dvig, ugrez, neznaten vertikalni premik 
In interpreting the adjusting structure of the Raša Fault, an interesting question arises related to the occurrence of the accompanying faults of the Idrija Fault, as represented on the Geological map of the Idrija-Cerkno Hills between Stopnik and Rovte 1: 25.000 (Mlakar \& Čar, 2009). Zala and Podgriže Fault are shown in Figure 5. The analogy with the Raša Fault is obvious, as the difference in size and the fact that the adjusting structure of the Idrija Fault indicate a greater degree of development, which would mean that the Idrija Fault is older than the Raša Fault. The latter is also confirmed by the fact that the Idrija Fault is bent as much as its bearing unit (the Trnovo Nappe opposite the Hrušica Nappe), while the Raša Fault is bent less than its bearing unit (northwestern part of the Trieste-Komen Anticlinorium opposite the southeastern part).

\section{Deformations of the Trieste-Komen Anticlinorium}

In addition to the bending of the major elements of the structure (Trieste-Komen Anticlinorium, Vipava Synclinorium, Trnovo Nappe opposite the Hrušišica Nappe) and the adjusting structures of the bent strike slip faults (Raša Fault, Idrija Fault), there are other deformations which are directly related to the bending. The most important are the Komen Wedge Structural Step (Komen Wedge Step), the Sistiana Sigmoidal Structure (Sistiana Sigmoid), the Ermada Push-out Block, and the Sistiana Push-out Block (Fig. 9).

Komen Wedge Structural Step. In the digital terrain model of Spodnji Kras (Fig. 10), a small difference in the average elevation of the Karst Plateau north and south of Komen (profile A) is visible in the Komen area. There is no such difference east of there, but towards the west it gradually increases and reaches about $100 \mathrm{~m}$ in the profile of Ivanji Grad (profile B). There is obviously a step there, which is wedge-shaped and runs in a westeast direction between Ivanji Grad and Komen. On the southwest side of the Divača Fault, west of Ivanji Grad, the step maintains its direction and reaches the Monte Cosici Hill (113 m) above Monfalcone. In a later tectonic development, it suffered several transformations west of the Divača Fault and collapsed into several sections but retained its original direction. In this article, we are interested in the Komen Wedge Structural Step as the primary phenomenon, and which originated together with the Sistiana Bending Zone, so we do not consider later deformations. For the purposes of this paper it is enough to conclude, that upon its formation it had a distinct wedge shape
Idrijsko-cerkljanskega hribovja med Stopnikom in Rovtami 1:25.000 (Mlakar \& Čar, 2009). Na sliki 5 sta zabeležena Zalin in Predgriški prelom. Analogija z Raškim prelomom je očitna, razlika je v velikosti in v tem, da kaže izravnalna zgradba Idrijskega preloma višjo stopnjo razvoja, kar bi pomenilo, da je Idrijski prelom starejši od Raškega. Slednje potrjuje tudi dejstvo, da je Idrijski prelom upognjen toliko kot njegova nosilna enota (Trnovski pokrov nasproti Hrušiškemu), Raški prelom pa manj od njegove nosilne enote (severozahodni del Tržaško-Komenskega antiklinorija nasproti jugovzhodnemu delu).

\section{Deformacije Tržaško - Komenskega antiklinorija}

Poleg upogiba večjih elementov strukture (Tržaško-Komenskega antiklinorija, Vipavskega sinljinorija, Trnovskega pokrova nasproti Hrušiškemu pokrovu) in izravnalnih struktur upognjenih zmičnih prelomov (Raški prelom, Idrijski prelom), obstajajo tudi druge deformacije, ki so neposredno povezane z upogibom. Najpomembnejše so komenski klinasti strukturni prag (komenski klinasti prag), sesljanska sigmoidna zgradba (sesljanska sigmoida), izrivna gruda Grmade in sesljanska izrivna gruda (sl. 9).

Komenski klinasti strukturni prag. Na digitalnem modelu reliefa Spodnjega Krasa (sl. 10) je na območju Komna vidna neznatna razlika $\mathrm{v}$ povprečni nadmorski višini kraške uravnave severno in južno od Komna (profil A). Te razlike vzhodno od tod ni, proti zahodu pa se postopoma veča in doseže v profilu Ivanji Grad že okoli $100 \mathrm{~m}$ (profil B). Obstaja torej prag, ki je klinaste oblike in ima med Ivanjim Gradom in Komnom smer zahod - vzhod. Na jugozahodni strani Divaškega preloma, zahodno od Ivanjega Grada, prag zadrži smer in sega do hriba Košnik / Monte Cosici (113 m) nad Tržičem / Monfalcone. V poznejšem tektonskem razvoju je prag zahodno od Divaškega preloma doživel več transformacij in razpadel na več odsekov, vendar je zadržal prvotno smer. $\mathrm{V}$ tem članku nas zanima kot primarni pojav, ki je nastal skupaj s sesljansko upogibno cono, zato kasnejših deformacij ne obravnavamo. Za ta prispevek zadostuje ugotovitev, da je ob svojem nastanku imel vzhodno od Divaškega preloma izrazito klinasto obliko, zahodno od le-tega pa je danes ta spremenjena. Profila Vojščica (profil C) in Sela na Krasu (profil D) kažeta stanje po več transformacijah. Na karti sta narisana Divaški in Selski prelom (Placer, 2015).

Konica klina leži v območju sesljanske upogibne cone. Že na prvi pogled je videti, da sesljanska upogibna cona ni nastala z bočnim 


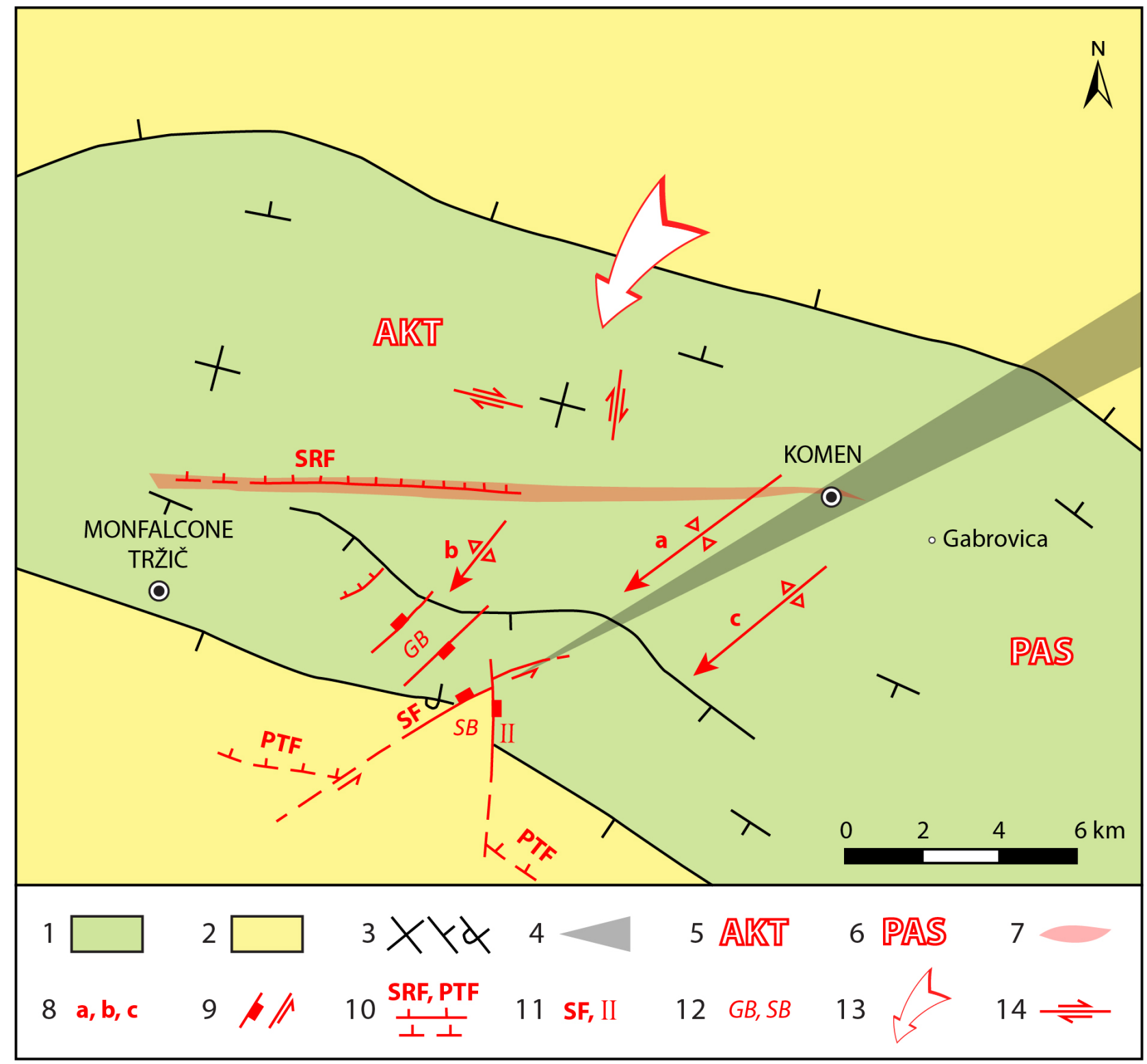

Fig. 9. Structures of the Sistiana Bending Zone in the Trieste-Komen Anticlinorium: Komen Wedge Structural Step, Sistiana Sigmoidal Structure, Monte Ermada Push-out Structure, Sistiana Push-out Block. Geological bases after Jurkovšek (2010) and Cucchi \& Piano (2013), structural bases after Placer (2015).

Sl. 9. Strukture sesljanske upogibne cone v Tržaško-Komenskem antiklinoriju: komenski klinasti strukturni prag, sesljanska sigmoidna zgradba, dvignjena gruda Grmade, sesljanska dvignjena gruda. Geološka osnova po Jurkovšek (2010) ter Cucchi in Piano (2013), strukturna osnova po Placer (2015).

1 Cretaceous, Paleocene and Eocene carbonates / kredni, paleocenski in eocenski karbonati

2 Eocene Transitional marlstone and Flysch / eocenski prehodni lapor in fliš

3 Bedding: horizontal, inclined, inverse / plasti: vodoravne, poševne, inverzne

4 Sistiana Bending Zone / sesljanska upogibna cona

5 Active block of bending zone (AKT) / aktivno krilo upogibne cone

6 Passive block of bending zone (PAS) / pasivno krilo upogibne cone (PAS)

7 Komen Wedge Structural Step / komenski klinasti strukturni prag

8 Sistiana Sigmoidal Structure / sesljanska sigmoidna zgradba: a - Gorjansko Syncline / Gorjanska sinklinala, b - Brestovica Anticline / Brestoviška antiklinala, c - Brje Anticline / Brska antiklinala

9 Steep fault: sign for subsided block, relative direction of displacement / strmi prelom: oznaka ugreznjenega krila, relativna smer premika

10 Reverse fault, thrust fault / reverzni prelom, narivni prelom: SRF - Sela Reverse Fault / Selski reverzni prelom, PTF Palmanova Thrust Fault / Palmanovski narivni prelom

$11 \mathrm{SF}$ - Sistiana Fault / Sesljanski prelom, II - fault no. II / prelom št. II

12 GB - Monte Ermada Push-out Block / izrivna gruda Grmade, SB - Sistiana Push-out Block / sesljanska izrivna gruda 13 Direction of external rotation of the active block of bending zone / smer eksterne rotacije aktivnega krila upogibne cone 14. Internal rotation, direction of displacement along the more important planes of the internal discontinuities / interna rotacija, smer premika vzdolž pomembnejših ploskev internih diskontinuitet 


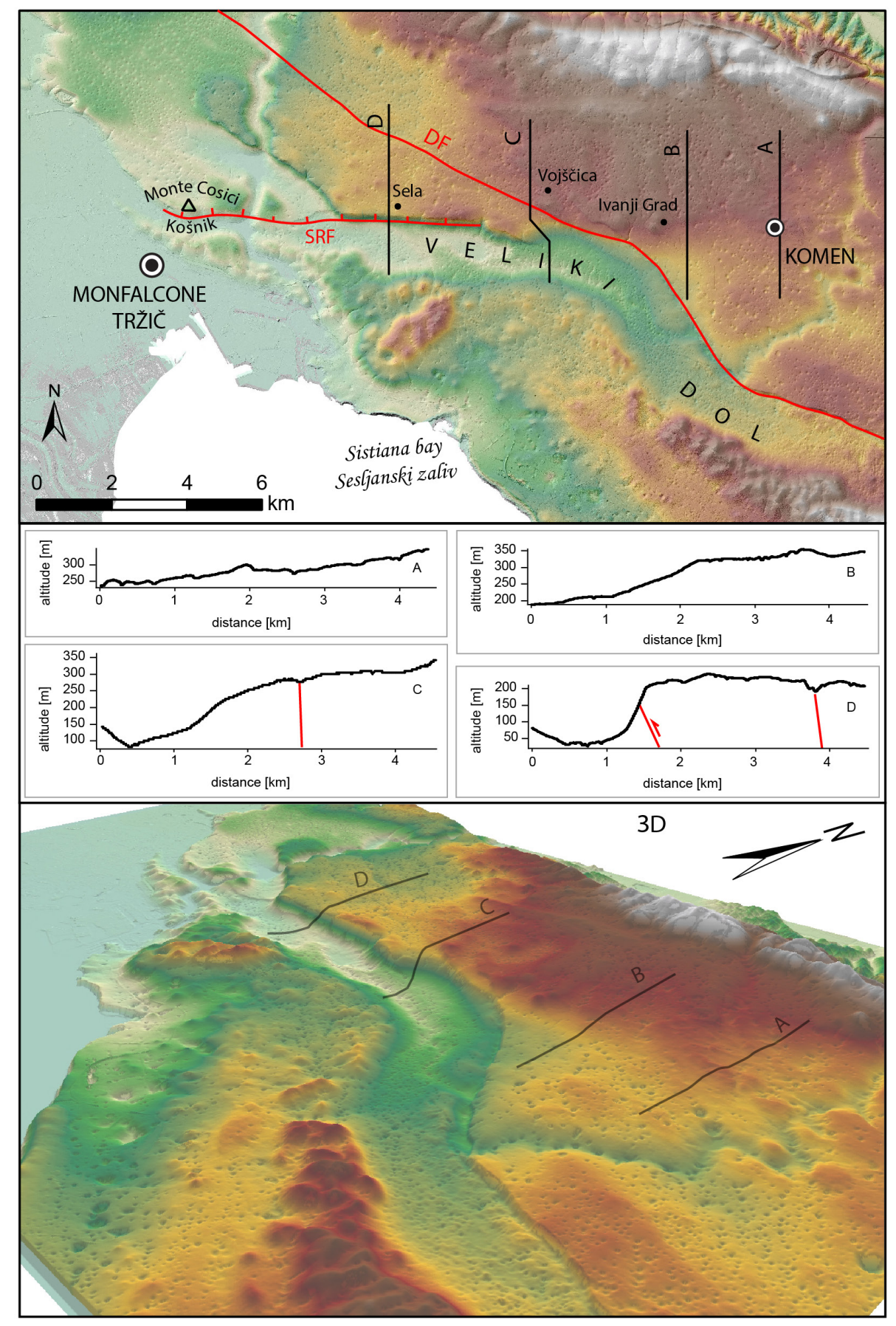

Fig. 10. Komen Wedge Structural Step. Topographic profiles.

Sl. 10. Komenski klinasti strukturni prag. Topografski profili.

A - Profile Komen / profil Komen

B - Profile Ivanji Grad / profil Ivanji Grad

C - Profile Vojščica / profil Vojščica D - Profile Sela na Krasu / profil Sela na Krasu

SRF - Sela Reverse Fault / Selski reverzni prelom

DF - Divača Fault / Divaški prelom

east of the Divača Fault, while west of the fault it is now modified. The profiles Vojščica (profile C) and Sela na Krasu (profile D) show the situation after several transformations. The map shows the Divača and Sela faults (Placer, 2015).

The tip of the wedge is positioned in the area of the Sistiana Bending Zone. It is apparent already upon first glance, that the Sistiana Bending Zone was not formed by a lateral bending characterized by a symmetrical structure, but by a pushing of the southeastern wing of the Sistiana Bending Zone in the northeast to east-northeast direction and a rotation of its northwest wing in a counter-clockwise direction (Fig. 9). Although upogibom za katerega je značilna simetrična zgradba, temveč pri potisku jugovzhodnega krila sesljanske upogibne cone proti severovzhodu do vzhodu-severovzhodu in rotaciji njenega severozahodnega krila v nasprotni smeri urinega kazalca (sl. 9). Čeprav obravnavamo Tržaško -Komenski antiklinorij, je pri opisovanju dogajanja bolje uporabljali izraz antiforma, ker gre $\mathrm{v}$ bistvu za veliko antiklinalo dinarske smeri $\mathrm{z}$ blago nagnjenimi krili in subhorizontalnim ter blago nagubanim širokim jedrom. V rotirajočem krilu so se napetosti kompenzirale $\mathrm{z}$ internimi zdrsi po obstoječih diskontinuitetah, zato je imelo v kinematskem smislu jugovzhodno krilo 
the Trieste-Komen Anticlinorium is examined, use of the term antiform is better, because it is basically a large anticline in the Dinaric direction with slightly inclined limbs and a sub-horizontal, slightly folded and broad hinge zone. In the rotating limb, the stresses were compensated by internal slips along the existing discontinuities, so in a kinematic sense the southeast wing of the bending zone played a passive role (PAS in Figs. 9 and 11) and the northwestern one an active role (AKT in Figs. 9 and 11). The rotational relaxation displacements in the active wing were compensated for by the bedding-planes, joints, and faults. According to the geological map (Jurkovšek, 2010; Cucchi \& Piano, 2013), the faults take a largely Dinaric (NW-SE) direction and are sub-vertical, or they dip steeply to the northeast, while the joints are sub-vertical and run in various directions, most often in the Dinaric and N-S direction. In the limbs of the active antiform, internal slips occurred mainly along the bedding-planes and to a minor extent along other discontinuities, so that a large, apparently oblique anticline formed in the northeastern wing; and in the southwestern wing, initially, apparently oblique synclines and later several normal folds formed. We use the qualifier "apparent," because they are actually monoclinic folds. In the central part of the active limb of the antiform, where the bedding was sub-horizontal, the internal rotation could not occur along the bedding-planes but along the joints and faults instead, most easily along the sub-vertical and as perpendicular as possible to the direction of the bending zone. upogibne cone pasivno vlogo (PAS na sl. 9 in 11), severozahodno pa aktivno (AKT na sl. 9 in 11). Razbremenilne premike rotacije v aktivnem krilu so prevzele lezike, razpoke in prelomi. Slednji so po podatkih geološke karte (Jurkovšek, 2010; Cucchi in Piano, 2013) imeli večinoma dinarsko smer NW-SE in bili subvertikalni ali vpadali strmo proti severovzhodu, razpoke so bile subvertikalne in imele različne smeri, pogoste so zlasti v dinarski smeri in v smeri N-S. V krilih aktivne antiforme so se interni zdrsi dogajali predvsem po lezikah in manj po drugih diskontinuitetah, tako je v severovzhodnem krilu nastala obsežna navidezna poševna antiklinala, v jugozahodnem krilu pa najprej navidezna poševna sinklinala, pozneje pa več normalnih gub. Navidezna zato, ker gre za monoklinalni gubi. $\mathrm{V}$ osrednjem delu aktivnega krila antiforme, kjer so bile plasti subhorizontalne, pa se interna rotacija ni mogla dogajati po lezikah temveč po razpokah in prelomih, najlažje po tistih, ki so bile subvertikalne in čim bolj pravokotne na smer upogibne cone.

Poenostavljeni kinematski model komenskega klinastega strukturnega praga je prikazan na sliki 11. Bistven pogoj za njegov nastanek so bile subhorizintalne plasti v jedru Tržaško-Komenskega antiklinorija in razbremenitev ob Selskem reverznem prelomu, ki je nastal v fazi narivanja in ne sega do sesljanske upogibne cone, temveč se izklini že okoli $8 \mathrm{~km}$ prej (sl. 9 in 10). Prelom je bil torej inicialna struktura po kateri je prišlo do reaktiviranja reverznega premika. Poleg reverzne je morala, v skladu s pravilom interne

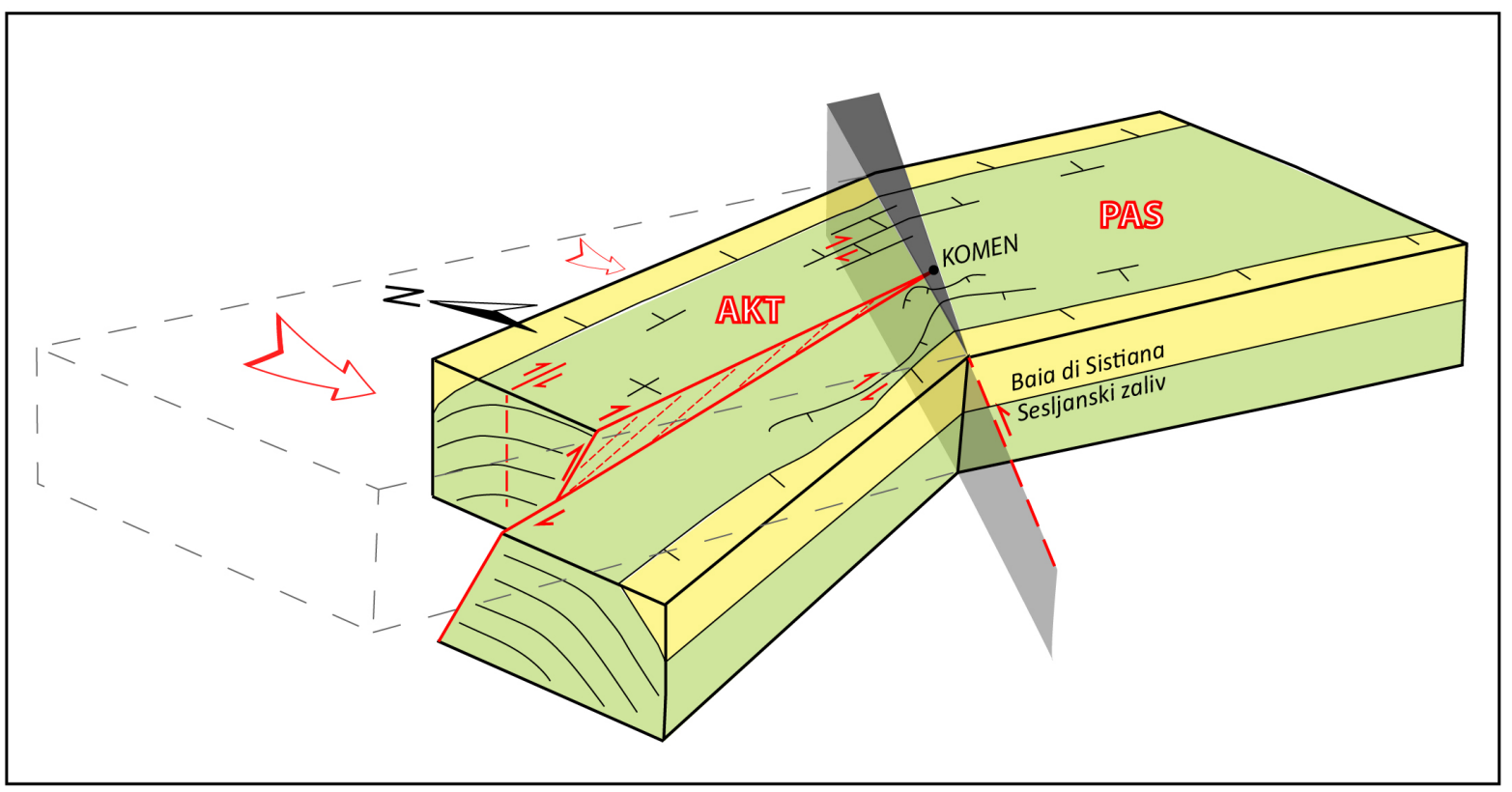

Fig. 11. Kinematic model of the Komen Wedge Structural Step. Legend in Fig. 9.

Sl. 11. Kinematski model komenskega klinastega strukturnega praga. Legenda na sl. 9. 
The simplified kinematic model of the Komen Wedge Structural Step is represented in Figure 11. The necessary prerequisite for its formation is the sub-horizontal bedding at the core of the Trieste-Komen Anticlinorium and the relaxation along the Sela Reverse Fault, which formed during the thrusting phase and does not reach as far as the Sistiana Bending Zone, but pinches-out some $8 \mathrm{~km}$ before (Figs. 9 and 10). The fault was therefore the initial structure along which the reverse displacement was reactivated. In addition to the reverse component, according to the internal rotation rule there must also be a weak right-lateral displacement component present. Instead of a reverse displacement, a flexure was formed to the east of the area, where the Sela Fault pinches-out, which shallowed in the eastward direction and disappeared at Komen on the axis of the Sistiana Bending Zone (Figs. 10 and 11). The formation of a wedge structural step is therefore the result of the rigidity of the central part of the antiform and the limited folding possibilities. It is clear from the geometry of the wedge structural step that its pronounced shape is developed only in its eastern part near the bending zone, while towards the west it is diminished or subjected to secondary processes.

Before the formation of the Komen Wedge Structural Step there were other existing faults other than the Sela Fault that were not reactivated. This is probably because the Sela Fault formed as a reverse fault and reactivated as such, while others, especially those in the Divača Fault Splay, formed as normal faults. As a result, greater friction was created due to the changed kinematics in their fault planes.

Sistiana Sigmoidal Structure. The north and south slopes of the Trieste-Komen antiform are deformed in different ways in the active wing of the bending zone. In the first case the bending was unimpeded, while in the second the area was confined. The Gorjansko Syncline formed here first as an apparent fold, and then from its limbs as the Brestovica Anticline in the northwestern and as the Brje Anticline in the southeastern wing of the bending zone, both of which were normal flexural folds. This is inferred from the fact that all three folds form a characteristic sigmoidal structure (Figs. 9 and 11). The Brje Anticline in the passive wing of the bending zone is less distinct than the Brestovica Anticline in the active wing. The folded area was mapped by Jurkovšek (2010), the folds were spatially determined by Placer (2015), and the names of folds were defined in this article.

The Gorjansko Syncline is integrated into the structure of the wedge structural step, so it must rotacije, obstajati tudi šibka desna horizontalna komponenta. Vzhodno od območja, kjer se Selski prelom izklini, je namesto reverznega premika nastala fleksura, ki se je proti vzhodu plitvila in pri Komnu izklinila v osi sesljanske upogibne cone (sl. 10). Nastanek klinastega praga je torej posledica togosti osrednjega dela antiforme in omejene možnosti gubanja. Iz geometrije klinastega praga izhaja, da ima izrazito klinasto obliko le njegov vzhodni del v bližini upogibne cone, proti zahodu pa se ta izgubi, oziroma je bila podvržena sekundarnim procesom.

Pred nastankom komenskega klinastega praga, so poleg Selskega preloma obstajali tudi drugi prelomi, ki pa niso bili reaktivirani. Vzrok tiči verjetno v tem, da je Selski prelom nastal kot reverzni in se kot tak reaktiviral, medtem ko so drugi, zlasti tisti $\mathrm{v}$ divaškem snopu prelomov, nastali kot normalni prelomi. Zaradi tega je bilo trenje ob spremenjeni kinematiki v njihovih prelomnih ploskvah večje.

Sesljanska sigmoidna zgradba. Severno in južno krilo Tržaško-Komenske antiforme je v aktivnem krilu upogibne cone različno deformirano. V prvem primeru je bil upogib neoviran, $\mathrm{v}$ drugem je bil prostor utesnjen. V utesnjenem delu je nastala najprej Gorjanska sinklinala, ki je bila zasnovana kot navidezna guba, nato pa iz njenih kril izhajajoči Brestoviška antiklinala v severozahodnem in Brska antiklinala $\mathrm{v}$ jugovzhodnem krilu upogibne cone, ki sta bili normalni fleksivni gubi. Na to sklepamo po tem, da tvorijo vse tri gube značilno sigmoidno zgradbo (sl. 9 in 11). Brska antiklinala $\mathrm{v}$ pasivnem krilu upogibne cone je manj izrazita od Brestoviške v aktivnem krilu. Območje gub je kartiral Jurkovšek (2010), prostorsko jih je izločil Placer (2015), poimenovane pa so bile v tem članku.

Gorjanska sinklinala je vključena v zgradbo klinastega praga, zato je morala biti zasnovana, ali celo nastati, pred začetkom njegove rasti. Če odnos Gorjanske sinklinale razširimo na celotno sigmoidno zgradbo, je klinasti prag moral nastati v zrelem obdobju razvoja sigmoidne zgradbe.

Izrivna gruda Grmade. Pomemben element Brestoviške antiklinale so prelomi v smeri SWNE severozahodno od Sesljanskega zaliva, ki ležijo v njenem apikalnem delu. Tip gube, prelomi in morfologija tega območja kažejo na dve fazi razvoja, v prvi je nastala guba, ki ima komponente fleksivnega gubanja v drugi fazi pa je prišlo zaradi nezmožnosti nadaljnega gubanja do izrivov posameznih blokov med prelomi vzporednimi osni ravnini gube, za katere domnevamo, da so se regenerirali po conah razpoklinskega 
have its roots, or was even formed, before it began to evolve. If we extend the Gorjansko Syncline relation to the entire sigmoidal structure, the wedge structural step must have originated during the mature period of the sigmoidal structure's development.

Ermada Push-out Block. The SW-NE directed faults northwest of the Sistiana Bay, which are positioned in its apical part, are important elements of the Brestovica Anticline. The type of fold, faults, and morphology of the area indicate two stages of evolution: the first is the formation of the fold, with components of flexural folding; and in the second stage, due to the impossibility of further folding, the individual blocks between the faults, parallel to the fold axis plane and presumably regenerated along the zones of fissure cleavage, were pushed out. In this way, a ridge of Ermada was formed between Ermada (323 m) and Ter (284 m), as well as some reverse faults (Fig. 9). Without detailed analysis, however, it is not possible to determine whether the two phases of evolution took place consecutively or periodically. The vertical displacement is inferred from the relief itself, while the strike-slip displacement interpreted by Cucchi \& Piano (2013) is based on an apparent horizontal movement.

Sistiana Push-out Block. Its formation is described in the description of the structure of Sistiana Bay in the chapter on the Sistiana Fault (Figs. 3 and 9).

Deformation sequence. Based on the relationship between the four structures of the Sistiana Bending Zone in the Trieste-Komen Anticlinorium, we can conclude the following:

1. The sigmoidal structure began to form before the Komen Wedge Structural Step.

2. The Komen Wedge Structural Step formed due to the limited possibility of contraction of the area in the sigmoidal structure and due to the rigidity of the central part of the anticlinorium.

3. The Komen Wedge Structural Step was formed after the formation of the level surface of the Trieste-Komen Anticlinorium.

4. The Grmada Push-out Block and one or two smaller blocks in the vicinity are the result of extreme contraction in the area of a sigmoidal structure.

5. The Sistiana Push-out Block is positioned along the Sistiana Fault. Its formation is related to the corresponding joint-fault framework and rotation of the active wing of the Sistiana Bending Zone. klivaža. Tako je nastal greben Grmade med Grmado / Ermada (323 m) in Terom (284 m) ter nekaj reverznih prelomov (sl. 9). Ali sta obe fazi potekali zaporedoma ali s prekinitvijo, brez podrobne analize ni mogoče ugotoviti. Da gre za vertikalno izrivanje kaže sam relief, interpretacija Cucchi-ja in Piano-ve (2013) z zmikanjem sloni na navideznem horizontalnem premiku.

Sesljanska izrivna gruda. Opis njenega nastanka je podan pri opisu zgradbe Sesljanskega zaliva v poglavju o Sesljanskem prelomu (sl. 3 in 9).

Zaporedje deformacij. Na podlagi razmerja med omenjenimi štirimi strukturami sesljanske upogibne cone v Tržaško-Komenskem antiklinoriju lahko sklenemo naslednje:

1. Sigmoidna zgradba je pričela nastajati pred komenskim klinastim pragom.

2. Komenski klinasti prag je pričel nastajati zaradi omejene možnosti krčenja prostora na območju sigmoidne zgradbe in zaradi togosti osrednjega dela antiklinorija.

3. Komenski klinasti prag je nastal po izoblikovanju uravnave na območju Tržaško-komenskega antiklinorija.

4. Izrivna gruda Grmade in ena ali dve manjši v bližini, so skrajni izraz krčenja prostora v območju sigmoidne zgradbe.

5. Sesljanska izrivna gruda leži ob Sesljanskem prelomu, njen nastanek je povezan z ustreznim razpoklinsko-prelomnim predrisom in rotacijo aktivnega krila sesljanske upogibne cone. 


\section{Deformation sequence}

From the characteristics of the Sistiana Bending Zone and its relationships with the fault deformations that cross it, we can establish a deformation sequence for the zone. The criteria for classifying faults preceding the formation of the Sistiana Bending Zone requires that they be as bent as the host tectonic unit. Such, for example, is the Paleodivača Fault, which is bent much like the Trieste-Komen Anticlinorium, and the Idrija Fault, whose bending is approximately the same as the degree of rotation of the Trnovo Nappe opposite the Hrušica Nappe.

The Raša Fault formed during the second half of the growth of the Sistiana Bending Zone, because its bending is smaller than for the Trieste-Komen Anticlinorium. After the bending and subsequent shearing, which may have been a single or multi-stage process, secondary faults of the adjusting structure formed. These, together with the main fault, may have been bent again, but no such research has been undertaken.

The associated faults of the Idrija Fault are included conditionally in the analysis; however, we can reasonably assume that they formed the same way they did at the Raša Fault. This remains an assumption due to the absence of mapping evidence of the trace of the Zala Fault and the Lome Zone towards the southeast (Fig. 5).

The morphology of the Komen Wedge Structural Step indicates that a leveled morphology prevailed before its formation. Since this is a leveled Trieste-Komen Anticlinorium, further research is required in order to open a discussion of the leveled areas inside the External Dinaric Imbricated Belt (parautochton) and their relation to the leveled areas of the External Dinaric Thrust Belt (allochthonous) and Microadria.

The Sistiana Bending Zone is an important indicator of the deformation sequence in a certain time period in a certain space after the formation of the Dinaric thrust structure. Said deformations will need to be related to deformations outside the area. The kinematic phases described in this article were formed in the following order:

1. The formation of the Sistiana Bending Zone evolved gradually in the direction of the pushing of the Istria Block towards the Dinarides. The precise direction of pushing has not yet been determined. At first, the northwestern part of the Trieste-Komen Anticlinorium began to rotate, then the process gradually extended to the Vipava Synclinorium and the Trnovo Nappe. Together with these units, disjunctive deformations inside them,

\section{Zaporedje deformacij}

Iz značilnosti sesljanske upogibne cone in njenih odnosov s prelomnimi deformacijami, ki jo prečkajo, je mogoče postaviti zaporedje deformacij tega območja. Merilo za uvrstitev prelomov v čas pred nastankom sesljanske upogibne cone je, da morajo biti enako usločeni kot tektonska enota v kateri ležijo. Tak je Paleodivaški prelom, ki je enako usločen kot Tržaško-Komenski antiklinorij, in Idrijski prelom, katerega usločenost je približno tolikšna, kot znaša zasuk Trnovskega pokrova nasproti Hrušiškemu pokrovu.

Raški prelom je nastal v drugi polovici rasti sesljanske upogibne cone, ker je njegova usločenost manjša od usločenosti Tržaško-Komenskega antiklinorija. Po usločitvi in ponovnem strigu, kar je bilo lahko enkratno ali večkratno dejanje, so nastali njegovi sekundarni prelomi izravnalne zgradbe. Ti bi bili skupaj z glavnim prelomom lahko domnevno ponovno usločeni, vendar raziskave v to smer niso bile opravljene.

Pridruženi prelomi Idrijskega preloma so vključeni v analizo pogojno, čeprav upravičeno domnevamo, da so nastali na enak način kot pri Raškem prelomu. Vzrok je v odsotnosti dokazov kartiranja o poteku Zalinega preloma in lomske cone proti jugovzhodu (sl. 5).

Morfologija komenskega klinastega strukturnega praga kaže na to, da je pred njegovim nastankom obstajala uravnava. Ker gre za uravnani Tržaško-komenski antiklinorij, bo pri nadaljnjih raziskavah potrebno odpreti razpravo o uravnavah znotraj Zunanjedinarskega naluskanega pasu (paravtohtona) in njihovem odnosu do uravnav Zunanjedinarskega narivnega pasu (alohtona) in Mikroadrije.

Sesljanska upogibna cona je pomemben kazalec zaporedja deformacij določenega časovnega obdobja in določenega prostora, po nastanku dinarske narivne zgradbe. Nanje bo potrebno vezati deformacije izven tega območja. V tem članku omenjene kinematske faze so nastale po naslednjem zaporedju:

1. Nastanek sesljanske upogibne cone je potekal postopoma $\mathrm{v}$ smeri potiskanja istrskega bloka proti Dinaridom. Natančnejša smer potiskanja še ni določena. Najprej se je pričel upogibati severozahodni del Tržaško-komenskega antiklinorija, na kar se je proces postopoma širil na Vipavski sinklinorij in Trnovski pokrov. Skupaj s temi enotami so se sukale tudi disjunktivne deformacije znotraj le-teh od Istrsko-furlanske podrivne cone do Paleodivaškega in Idrijskega preloma. Začetek nastajanja 
from the Istra-Friuli Underthrust Zone to the Paleodivača and Idrija faults, also underwent rotation. Determination of the start of the formation of the Sistiana Bending Zone could be possible with an analysis of the cave sediments in the active wing of the Sistiana Bending Zone in the Trieste-Komen Anticlinorium.

2. In conjunction with the rotation of a part of the Trieste-Komen Anticlinorium the Gorjansko Syncline, the oldest structure of the Sistiana Sigmoidal Structure, began to form.

3. The Komen Wedge Structural Step began to form after the formation of the Gorjansko Syncline and before the formation of the Sistiana Sigmoidal Structure. The leveling of the Trieste-Komen Anticlinorium predates the Komen Wedge Structural Step.

4. The Raša Fault formed after a relatively extended period of growth of the Sistiana Bending Zone.

5. The Raša Fault bent in the further evolution of the bending zone. The reverse component of displacement along the fault with the uplifting NE block is likely to develop or begin to develop at this stage.

6. An adjusting structure of the Raša Fault is formed in the right-lateral shearing conditions, which gradually includes the Lukovica, Kobjeglava, and Tomačevica faults. It is unclear whether all three adjusting faults represent three stages of bending and displacement or whether this is simply a continuous process.

7. Assuming that the adjusting structure of the Raša Fault is bent, the bending zone started to grow again. Finally, the Sistiana Sigmoidal Structure and the Ermada Push-out Block have been fully developed. The Sistiana Push-out Block is also formed. The originally uniform Komen Wedge Structural Step assumes its present fragmented appearance, but its formation is also related to other processes.

8. Recent dynamics is a matter of detailed geodetic surveying and proper interpretation; the position of the geodetic points would have to be based on a sound theoretical framework.

The timing of the inception or formation of the individual phases and dynamics of the events constitutes the fundamental issue of the described deformation sequence. We know only a little about this now, but we can roughly estimate the timing for the inception of the Raša right-lateral strike sesljanske upogibne cone bi bilo mogoče določiti z analizo jamskih sedimentov aktivnega krila sesljanske upogibne cone $\mathrm{v}$ Tržaško-komenskem antiklinoriju.

2. Skupaj s sukanjem dela Tržaško-Komenskega antiklinorija je pričela nastajati Gorjanska sinklinala, ki je najstarejši člen sesljanske sigmoidne zgradbe.

3. Komenski klinasti strukturni prag je pričel rasti po nastanku Gorjanske sinklinale in pred dokončnim izoblikovanjem sesljanske sigmoidne zgradbe. Uravnava Tržaško-Komenskega antiklinorija je starejša od komenskega klinastega praga.

4. Raški prelom je nastal po sorazmerno daljšem obdobju rasti sesljanske upogibne cone.

5. Pri nadaljnji rasti upogibne cone se je Raški prelom usločil. V tej fazi verjetno nastane, ali prične nastajati, reverzna komponenta premika severovzhodnega krila preloma.

6. V desnostrižnih pogojih nastane izravnalna zgradba Raškega preloma, ki postopoma vključuje Lukovški, Kobjeglavski in Tomačevski prelom. Ni jasno ali trije izravnalni prelomi pomenijo tri faze upogibanja in zmikanja, ali gre za kontinuiran proces.

7. Če privzamemo domnevo, da je izravnalna zgradba Raškega preloma usločena, se po njenem nastanku prične ponovna rast upogibne cone. Do sedanjega stanja se dokončno razvije sesljanska sigmoidna zgradba in izrivni blok Grmade. Nastane tudi sesljanska izrivna gruda. Prvotno enoten komenski klinasti strukturni prag dobi sedanjo fragmentirano podobo, vendar je njgov nastanek povezan tudi z drugimi procesi.

8. Sedanje dogajanje je stvar podrobnih geodetskih meritev in ustrezne interpretacije. V ta namen je potrebno postaviti merske točke na podlagi trdnega teoretskega modela.

Temeljni vprašanji opisanega zaporedja sta čas nastanka ali nastajanja posameznih faz in dinamika dogajanja. O tem vemo v tem trenutku malo, vsaj približno pa lahko ocenimo čas nastanka Raškega desnozmičnega preloma. Ob Raškem prelomu je v Ilirski Bistrici nastal pull apart-ski bazen (Placer in Jamšek, 2011), v katerem se je sedimentiral premog in nad njim okoli 100 m gline. Ta je po Osnovni geološki karti srednjepliocenske starosti (Šikić in Pleničar, 1975). Podatki so posredni, pridobljeni so bili po primerjavi prikamnin premoga iz rudarskih del $\mathrm{v}$ premogovniku in vrtinah, kjer niso našli fo- 
slip fault. Along the Raša Fault, a pull-apart basin formed at Ilirska Bistrica (Placer \& Jamšek, 2011), in which coal deposited with some $100 \mathrm{~m}$ of clay over the top. According to the Basic Geological Map (Šikić \& Pleničar, 1975) it is of Middle Pliocene age. However, the related age-data obtained is only indirect, and was determined by comparing the host rock of the coal from mining works and boreholes free of fossils with similar strata in Istria (Petraschek, 1926/26). A Mastodon arvenensis was found here, whose age was used to date the basin. The age of the horizon at the lower part of the basin would be about 3.6 myr based on the International Chronostratigraphic Chart (2020/03). The fault formed earlier, probably in the Lower Pliocene or some 5 million years ago. This data is consistent with the results of the modeling of the shear heating connected with heat flow data, which indicates that displacements along the regional right-lateral strike-slip faults in southwestern Slovenia started at the beginning of the Pliocene (Caporali et al., 2013). The Raša Fault originated in the second half of the evolution of the Sistiana Bending Zone, so the onset of such is probably far older.

Moulin et al. (2016) propose activation of the right-lateral strike-slip displacement along the Raša Fault in the Early to Middle Pleistocene, and along the Idrija Fault in the Late Pliocene, based on geomorphological data for western Slovenia. In both cases, the data is valid for a particular segment, which may or may not apply to the entire fault. In addition, calculations assume that a constant average displacement velocity along the faults, which also may or may not be the case. In general, the onset of the regional phase of right-lateral strike-slip activity along the Dinaric faults is set in the beginning of the Pliocene (Vrabec \& Fodor, 2006; Čar, 2010; Žibert \& Vrabec, 2016).

We have shown that the Paleodivača and Idrija faults originated before the evolution of the Sistiana Bending Zone. The Belsko Fault has not been sufficiently investigated, so it is reasonable to leave it aside; it is mentioned only because it is significantly deformed in the area between the Hrušica and Trnovo Nappes in the Sistiana Bending Zone. Among the faults, only the Raša Fault originated during the growth of the bending zone; as a result, it represents a suitable subject for investigations of the dynamics of bending, right-lateral strikeslip displacements, and formation of the adjusting faults. The initiation and mechanism of the evolution of the Raša Fault is not the subject of this paper. Assuming a constant counter-clockwise rotation of the Adria Microplate (Weber et al., 2010) and the constant growth of the Istra Pushed silov, s plastmi v Istri (Petraschek, 1926/29). Tu je bil najden Mastodon arvenensis, po katerem so sklepali na starost. Po današnji mednarodni časovni lestvici (2020/03) bi bile plasti spodnjega dela bazena potemtakem stare okoli 3,6 milijona let. Prelom je moral nastati pred tem, verjetno $\mathrm{v}$ spodnjem pliocenu ali na njegovem začetku pred približno 5 milijoni leti. Ta podatek se ujema $z$ rezultati modeliranja strižnega segrevanja prostora $\mathrm{v}$ povezavi s podatki toplotnega toka, ki nakazujejo, da so se premiki ob regionalnih desnozmičnih prelomih v jugozahodni Sloveniji pričeli v začetku pliocena (Caporali in sodelavci, 2013). Raški prelom je nastal v drugi polovici razvoja sesljanske upogibne cone, zato je začetek njenega nastajanja precej starejši.

Aktivacijo desnozmičnega premika ob Raškem in Idrijskem prelomu na podlagi geomorfoloških podatkov v zahodni Sloveniji, umeščajo Moulin in sodelavci (2016) za Raški prelom v spodnji do srednji pleistocen, za Idrijski prelom v zgornji pliocen. Seveda gre v obeh primerih za podatke določenega segmenta, ki morda ne veljajo za celotni prelom. Poleg tega temeljijo izračuni na predpostavki, da je bila povprečna hitrost premika ob prelomih ves čas enaka, kar morda ne drži. Na splošno je začetek regionalne faze desnozmične aktivnosti ob dinarskih prelomih postavljen v začetek pliocena (Vrabec \& Fodor, 2006; Čar, 2010; Žibert \& Vrabec, 2016).

Videli smo, da sta Paleodivaški in Idrijski prelom nastala pred pričetkom rasti sesljanske upogibne cone. Belski prelom še ni dovolj raziskan, zato ga je smiselno pustiti ob strani, omenjen je le zato, ker je na prostoru med Hrušiškim in Trnovskim pokrovom, torej v območju sesljanske upogibne cone, močno deformiran. Od ostalih je med rastjo upogibne cone zanesljivo nastal le Raški prelom, ki je zato primeren za študij dinamike upogibanja, desnega zmikanja in nastajanja izravnalnih prelomov. Vzrok in mehanizem nastanka Raškega preloma ni predmet obravnave tega članka. Pri predpostavljeni konstantni rotaciji Jadranske mikroplošče v nasprotni smeri urinega kazalca (Weber et al., 2010) in konstantni rasti Istrskega potisnega območja, bi po nastanku Raškega preloma proces lahko tekel po treh kinematskih scenarijih: 1 . Hkratno ukrivljanje prelomne ploskve v sesljanski upogibni coni in desno zmikanje, ki je lahko vodoravno ali poševno; ko zmikanje po glavni prelomni ploskvi ni več mogoče, nastane izravnalni prelom. 2. Izmenično ukrivljanje in zmikanje; v fazi ukrivljanja so mogoči tudi reverzni premiki. 3. Tektonska zrcala in neravne zglajene 


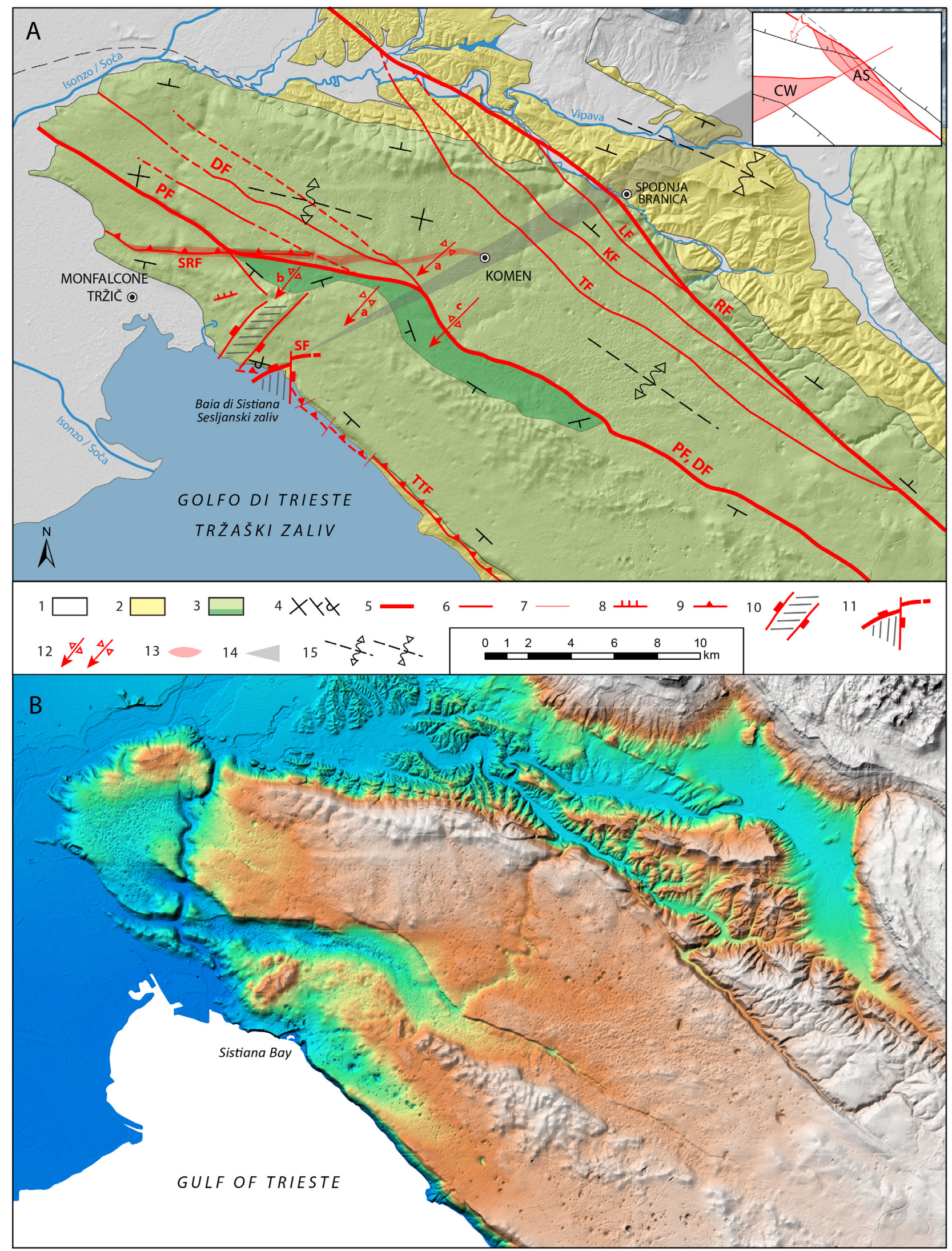

Fig. 12. DTM of the Sistiana Bending Zone. A. Structural basis after Simplified Structural-geological Map of Kras (Placer 2015). CW - Timavo Compressional Wedge; AS - Adjusting structure of the Raša Fault; B. DTM.

Sl. 12. Relief sesljanske upogibne cone. A. Strukturna podlaga po Poenostavljeni strukturno-geološki karti Krasa (Placer 2015). CW - Timavski kompresijski klin; AS - Izravnalna zgradba Raškega preloma; B. Relief. 
Area following the initiation of the Raša Fault, the process could have evolved according to one of three kinematic scenarios: 1 . Simultaneous bending of the fault plane in the Sistiana Bending Zone and horizontal or oblique right-lateral strike-slip displacement; when movement along the principal fault plane is no longer possible, the adjusting fault is formed. 2. Alternate bending and strikeslip displacement; during the bending phase, reverse displacements are also possible. 3 . Tectonic mirrors and unevenly smoothed planes in the Raša Fault Zone indicate a mixed scenario, in addition to the planes with sub-horizontal and sub-vertical slickensides. This question cannot be definitively answered without a detailed investigation.

\section{Conclusions}

Analysis of the Sistiana Bending Zone provided new insight into a certain section of the Istra Pushed Area deformation sequence and suggests the possibility of future qualitative and quantitative studies of the structure and dynamics of the northeastern part of Microadria.

The Sistiana Push-out Block, the sigmoidal structure with the Ermada Push-out Block, the Komen Wedge Structural Step, and the adjusting structure of the Raša Fault (Fig. 12) are the most prominent structural effects of the evolution of the Sistiana Bending Zone in the Trieste-Komen Anticlinorium.

The Wedge-shaped Structural Step and adjusting faults are new terms in the geological literature.

The sigmoidal structure finally evolved in the area between the Komen Wedge Structural Step and the Sistiana Bending Zone. We propose name Timavo Compressional Wedge for this particular ploskve v coni Raškega preloma, poleg ploskev z subhorizontalnimi in subvertikalnimi drsami, kažejo na mešani scenarij. Na to vprašanje ne bo mogoče odgovoriti brez detajlnih raziskav.

\section{Sklepi}

Analiza sesljanske upogibne cone je dala vpogled v določeni izsek zaporedja deformacij Istrskega potisnega območja in nakazala možnost nadaljnega kvalitativnega in kvantitativnega študija zgradbe in dinamike severovzhodnega dela Mikroadrije.

Najvidnejše strukturne posledice nastanka sesljanske upogibne cone v Tržaško-komenskem antiklinoriju so sesljanska izrivna gruda, sigmoidna zgradba z izrivno grudo Grmade, komenski klinasti strukturni prag in izravnalna zgradba Raškega preloma (sl. 12).

Klinasti strukturni prag opisanega tipa in izravnalni prelomi predstavljajo novosti v geološki literaturi.

Sigmoidna zgradba se je dokončno izoblikovala na prostoru med komenskim klinastim strukturnim pragom in sesljansko upogibno cono, ki ga zaradi oblike in lažjega sporazumevanja imenujemo timavski kompresijski klin. Ta predstavlja specifični strukturni objekt, ki združuje več vidikov kompresije; narivanje, gubanje, izrivanje in interne razbremenilne zdrse (sl. 12).

Sesljanska upogibna cona je nastajala dolgo obdobje, začetek njenega nastajanja je starejši od 5 milijonov let. Današnje stanje je mogoče oceniti po razmerah v Sesljanskem zalivu, kjer je Sesljanski prelom presekan s prelomom št. IV (30/80) (sl. 4) in nekaj šibkejšimi prelomi severno od tod. Zaradi tega verjetno ni več aktiven, ali pa je njegova aktivnost sekundarnega pomena. Po

Fig. 12. / Sl. 12.

3 Carbonates of Cretaceous, Paleocene, and Eocene age. Darker green Brje Formation of Early Cretaceous age, the oldest outcropping unit in the Trieste-Komen Anticlinorium / karbonati kredne, paleocenske in eocenske starosti, temnejše zeleno Brska formacija spodnjekredne starosti, najstarejše razgaljene plasti Tržaško-Komenskega antiklinorija

4 Dip of bedding / vpad plasti

5 Principal faults / glavni prelomi: RF - Raša Fault / Raški prelom, PF - Paleodivača Fault / Paleodivaški prelom, SF Sistiana Fault / Sesljanski prelom

6 Secondary faults / drugotni prelomi: LF - Lukovica Fault / Lukovški prelom, KF - Kobjeglava Fault / Kobjeglavski prelom, TF - Tomačevica Fault / Tomačevski prelom, DF - Divača Fault (northwestern part) / Divaški prelom (severozahodni del)

7 Tear fault / raztržni prelom

8 Reverse fault in the Timavo compressional wedge / reverzni prelom v timavskem kompresijskem klinu

9 Reverse and thrust fault of the Istra-Friuli Underthrust Zone / reverzni in narivni prelom istrsko-furlanske podrivne cone: SRF - Sela Reverse Fault / Selski reverzni prelom, TTF - Trieste Thrust Fault / Tržaški narivni prelom 10 Monte Ermada Push-out Block / izrinjena gruda Grmade

11 Sistiana Push-out Block / sesljanska izrivna gruda

12 Sistiana Sigmoidal Structure / sesljanska sigmoidna zgradba: a - Gorjansko Syncline / Gorjanska sinklinala, b - Brestovica Anticline / Brestoviška antiklinala, c - Brje Anticline / Brska antiklinala

13 Komen Wedge Structural Step / komenski klinasti strukturni prag

14 Sistiana Bending Zone / sesljanska upogibna cona

15 Axis of the Trieste-Komen Anticlinorium and Vipava Synclinorium (Planina Syncline) / os Tržaško-Komenskega antiklinorija in Vipavskega sinklinorija (Planinska sinklinala) 
area. This is a specific structural object that combines several aspects of compression: thrusting, folding, push-out, and internal relaxation displacements (Fig. 12).

The Sistiana Bending Zone evolved over a long period of time, which began more than 5 million years ago. The current situation in the Zone can be inferred from the situation in the Sistiana Bay, where the Sistiana Fault is cut by fault no. IV (30/80) (Fig. 4) and some less important faults further north. As a result, it is probably no longer active, or its activity is of secondary importance. By analogy, the Sistiana Fault is probably cut by faults, positioned south of fault no. IV (Fig. 3).

The rate of bending decreases gradually towards the northeast in the active wing of the Sistiana Bending Zone. The adjusting structure of the Idrija Fault is also included in the conclusions, although it is only hypothetically related to the Sistiana Bending Zone (Fig. 5). The lateral deformation of the Belsko Fault is different because of factors, which are not addressed in this article.

The direction of the Sistiana Fault offshore in the Trieste Bay is most likely indicated by the direction of the bending zone.

After describing the Sistiana Bending Zone, it is possible to execute an in-depth study of the relationship between the External Dinarides and the active Microadria. analogiji verjetno sekajo Sesljanski prelom tudi prelomi južno od preloma št. IV (sl. 3).

Velikost upogiba aktivnega krila sesljanske upogibne cone se proti severovzhodu polagoma manjša. V zaključke je vključena tudi izravnalna zgradba Idrijskega preloma, čeprav je s sesljansko upogibno cono povezana hipotetično (sl. 5). Bočna deformacija Belskega preloma je drugačna zaradi dejavnikov, ki jih v tem članku nismo obdelali.

Smer upogibne cone zelo verjetno nakazuje tudi smer Sesljanskega preloma v podmorju Tržaškega zaliva.

Po opisu sesljanske upogibne cone je mogoče pristopiti k poglobljenemu študiju razmerja med Zunanjimi Dinaridi in aktivno Mikroadrijo.

\section{Reference}

Blašković, I. \& Aljinović, B. 1981: Mikrotektonski elementi kao osnova za model tektonske građe šireg područja Kvarnera = Microtectonic elements as a basis for tectonic model of the broader Kvarner area. Simp. Kompleksna naftno-geološka problematika podmorja i priobalnih djelova Jadranskog mora, Split, Zbornik radova $=$ Proceedings, 87-100, Zagreb.

Blašković, I. 1991: Raspored uzdužnih, reversnih i normalnih rasjeda i konstrukcija oblika i dubina ploha podvlačenja = Disposition of the longitudinal, reverse and normal faults and depths of the underthrusting surfaces. Geol. vjesnik, 44: 247-256.

Busetti, M., Volpi, V., Nicolich, R., Barison, E., Romeo, R., Baradello, L., Brancatelli, G., Giustiniani, M., Marchi, M., Zanolla, C., Wardell, N., Nieto, D. \& Ramella, R. 2010: Dinaric tectonic features in the Gulf of Trieste (northern Adeiatic Sea). Bollettino di Geofisica Teorica ed Applicata, 51/2-3:117-128.
Caporali, A., Neubauer, F., Ostini, L., Stangl, G. \& Zulian, D. 2013: Modeling surface GPS velocities in the Southern and Eastern Alps by finite dislocations at crustal depths. Tectonophysics, 590: 136-150.

Carulli, G. B. \& Cucchi, F. 1991: Proposta di interpretazione strutturale del Carso triestino $=$ Proposal of geostructural interpretation of the Karts of Trieste. Atti Ticinesi di Scienze della Terra, 34: 161-166.

Carulli, G. B. (curated by) 2006: Carta geologica del Friuli Venezia Giulia 1:150.000 = Geological map of the Friuli Venezia Giulia 1:150.000. Ed. Regione Autonoma Friuli Venezia Giulia, Direzione centrale ambiente e lavori pubblici - Servizio geologico.

Carulli, G. B. 2011: Structural model of the Trieste Gulf: A proposal. Journal of Geodynamics, 51/2-3: 156-165. https://doi.org/10.1016/J. JOG.2010.05.004

Cucchi, F. \& Piano, C. (curated by) 2013: Carta geologica del Carso Classico Italiano 1:50.000. Ed. Regione Autonoma Friuli Venezia Giulia, 
Direzione centrale ambiente e lavori pubblici - Servizio geologico.

Cunningham, W. D. \& Man, P. 2007: Tectonics of strike-slip restraining and releasing bends. Geological Societi, London, Special Publications 2007, 290: 1-12.

Čar, J. 2010: Geološka zgradba idrijsko-cerkljanskega hribovja. Tolmač h Geološki karti idrijsko-cerkljanskega hribovja med Stopnikom in Rovtami v merilu 1:25.000 = Geological Structure of the Idrija-Cerkno hills. Explanatory book to the Geological map of the Idrija-Cerkno hills between Stopnik and Rovte 1:25.000. Geological Survey of Slovenia, Ljubljana: $127 \mathrm{p}$.

Historical Maps of the Habsburg Empire. The Second Military Survey (1806-1869). http:// mapire.eu/en/

International chronostratigraphic chart. Internatiolal Commission on Stratigraphy 2020/03. www.stratigraphy.org

Jurkovšek, B. 2010: Geološka karta severnega dela Tržaško - komenske planote 1:25.000 = Geological map of the Northern part of the Trieste-Komen plateau 1:25.000. Geološki zavod Slovenije, Ljubljana.

Jurkovšek, B., Cvetko Tešović, B., Kolar Jurkovšek, T. 2013: Geologija Krasa = Geology of Kras. Geological Survey of Slovenia, Ljubljana: 205 p.

Makar, I. \& Čar, J. 2009: Geološka karta idrijsko - cerkljanskega hribovja med Stopnikom in Rovtami 1: 25.000 = Geological map of the Idrija - Cerkno hills between Stopnik and Rovte 1:25.000. Geological Survey of Slovenia, Ljubljana.

Moulin, A., Benedetti, L., Rizza, M., Jamšek Rupnik, P., Gosar, A., Bourles, D., et al. 2016: The Dinaric fault system: large-scale structure, rates of slip, and Plio-Pleistocene evolution of the transpressive northeastern boundari of the Adria microplate. Tectonics, 35/10: 22582292. https://doi.org/10.1002/2016TC004188

Nicolich, R., Della Vedova, B. \& Giustiniani, M. (eds.) 2004: Carta del Sottosuolo della Pianura Friulana = Map of subsurface structures of the Friuli Plain. Regione Autonoma Friuli Venezia Giulia.

Osnovna geološka karta Jugoslavije (OGK) 1:100.000 = Basic geological map of Yugoslavia 1:100.000. Savezni geološki zavod, Beograd.

Petraschek, W. 1926/29: Kohlengeologie der Oesterreichischen Teilstaaten. Katowice.

Placer, L. 1981: Geološka zgradba jugozahodne Slovenije $=$ Geologic structure of southwestern Slovenia. Geologija, 24/1: 27-60.
Placer, L. 1994/95: O zgradbi Soviča nad Postojno $=$ On the structure of Sovič above Postojna. Geologija, 37/38: 551-560. https://doi. org/10.5474/geologija.1995.020

Placer, L. 2008: Principles of the tectonic subdivision of Slovenia. Geologija, 51/2: 205-217.

Placer, L., Vrabec, M. \& Celarc, B. 2010: The bases for undestanding of the NW Dinarides and Istria Peninsula tectonics. Geologija, 53/1: 5586. https://doi.org/10.5474/geologija.2010.005

Placer, L. \& Jamšek, P. 2011: Ilirskobistriški fosilni plaz - mesto na plazu $=$ The Ilirska Bistrica fossil landslide - The town on the landslide. Geologija, 54/2: 223-228.

Placer, L. 2015. Simplified structural map of Kras: Kras (Slovene), Carso (Italian) = Geographical unit. Geologija, 58/1, 89-93. https://doi.org/10.5474/geologija.2015.008

Placer, L., Mihevc, A. \& Rižnar, I. 2021: Tectonics and gravitational phenomena $($ Nanos, Slovenia $)=$ Tektonika in gravitacijski pojavi (Nanos, Slovenija). Geologija 64/1, 35-63, Ljubljana. https://doi.org/10.5474/ geologija.2021.002

Stache, G. 1920: Nachtrag zur Geologischen Spezialkarte Görz und Gradisca 1:75.000. Geologischen Staatsanstalt, Wien.

Swanson, M. T. 2005: Geometry and kinematics of adhesive wear in brittle strike-slip fault zones. Journal of Structural Geology, 27/5: 871887. https://doi.org/10.1016/j.jsg.2004.11.009

Šikić, D. \& Pleničar, M. 1975: Osnovna geološka karta Jugoslavije 1:100.000 = Basic geological map of Yugoslavia 1:100.000. Tolmač / Guideboock. List / sheet Ilirska Bistrica. Savezni geološki zavod, Beograd.:44 p.

Šikić, D. \& Polšak, A. 1973: Osnovna geološka karta Jugoslavije 1:100.000 = Basic geological map of Yugoslavia 1:100.000. Tolmač / Guideboock. List Labin / sheet Labin. Savezni geološki zavod, Beograd.

Venturini, S. 2002: Il pozzo di Cargnacco 1: un punto di taratura stratigrafica nella pianura friulana $=$ The well Cargnacco 1: a stratigraphic reference in the Friuli plain (northeastern Italy. Mem. Soc. Geol. It. (Roma), 57: 11-18.

Vrabec, M. \& Fodor, L. 2006: Late Cenozoic Tectonics of Slovenia: Structural Styles at the Northeastern Corner of the Adriatic Microplate. The Adria Microplate: GPS Geodesy, Tectonics and Hazard. NATO Science Series: IV: Earth and Environmental Sciences, 61. Dordrecht. https://doi. org/10.1007/1-4020-4235-3_10 
Weber, J., Vrabec, M., Pavlovčič Prešeren, P., Dixon, T., Jiang, Y. \& Stopar, M. 2010: GPSderived motion of the Adriatic microplate from Istria Peninsula and Po Plain sites, and geodynamic implications. Tectonophysics, 483/3-4: 214-222. https://doi.org/10.1016/j. tecto.2009.09.001
Žibret, L. \& Vrabec, M. 2016: Paleostress and kinematic evolution of the orogen-parallel NW-SE stricing faults in the NW External Dinarides of Slovenia unraveled by mesoscale fault-slip data analysis. Geologia Croatica, 69/3: 295305. https://doi.org/10.4154/gc.2016.30 